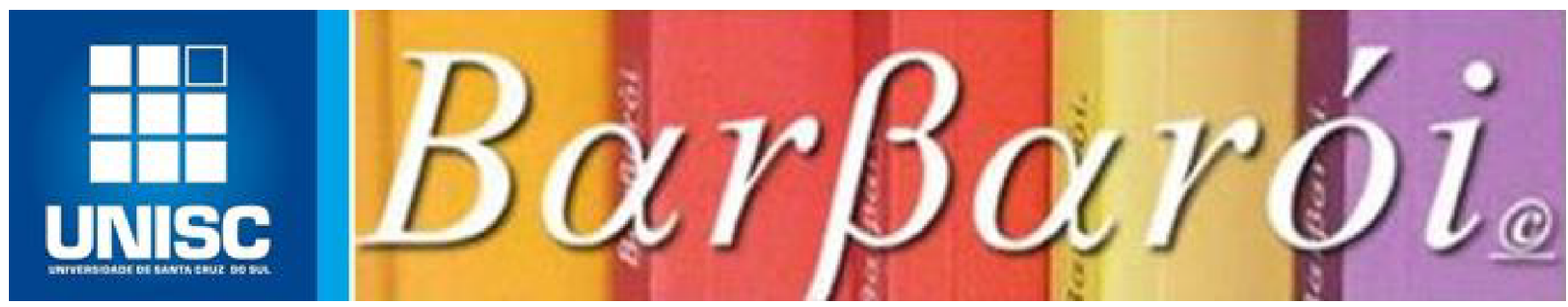

\title{
CIÊNCIAS HUMANAS E A FORMAÇÃO UNIVERSITÁRIA: UMA ANÁLISE A PARTIR DA EXPERIÊNCIA DA UNISC.
}

DOI: http://dx.doi.org/10.17058/barbaroi.v0i59.16983

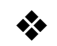 \\ Marcos Moura Baptista dos Santos \\ Entrevistado - Universidade de Santa Cruz do Sul - UNISC - Brasil \\ César Hamilton Brito de Goes \\ Entrevistador - Universidade de Santa Cruz do Sul - UNISC - Brasil \\ Marco André Cadoná \\ Entrevistador - Universidade de Santa Cruz do Sul - UNISC - Brasil
}

\section{Resumo:}

$\mathrm{Na}$ entrevista, o professor Marcos Moura Baptista dos Santos considera sua experiência na gestão da UNISC, tanto na condição de Pró-Reitor do Planejamento quanto na condição de Chefe do Departamento de Ciências Humanas, para analisar as mudanças que ocorreram, ao longo da história, nas experiências das Universidades Comunitárias. Contextualiza o processo político que resultou na criação da UNISC, no início da década de 1990, avalia as mudanças que ocorreram nas diferentes gestões da UNISC e problematiza as mudanças recentes, ocorridas num contexto de crise econômica e política que repercute na própria experiência histórica de Universidade no Brasil. Ao mesmo tempo, o professor Marcos considera as mudanças que ocorrem no processo de formação universitária, em especial nas Universidades Comunitárias, considerando essas mudanças desde os compromissos assumidos pelas Universidades Comunitárias em suas histórias.

\section{Palavras-chave:}

Universidades Comunitárias; Gestão Universitária; Formação Universitária; Humanidades e Formação Universitária. 


\section{Entrevistadores:}

Professor Marcos. Nossas entrevistas, realizadas com colegas do Departamento de Ciências Humanas, mas, também, com professores Vilmar Thomé e Carmem Lúcia (que, juntamente com o professor Luiz Augusto, são os que até então ocuparam o cargo de Reitor/a na UNISC) seguem um roteiro previamente construído. Nesse roteiro procuramos provocar reflexões sobre as trajetórias profissionais na UNISC; sobre a experiência de Universidade Comunitária, os desafios e os limites implicados nessa experiência histórica de construção das instituições universitárias no Brasil; sobre a crise da Universidade na atualidade, em especial a Universidade Comunitária; sobre a história do Departamento de Ciências Humanas na UNISC, a atual dissolução do Departamento e sua "imersão" numa nova estrutura organizacional na UNISC; e, é claro, sobre as humanidades na formação universitária, em especial e considerando a experiência de Universidade Comunitária.

Assim, gostaríamos de iniciar com o "resgate" de sua inserção profissional na UNISC. Em que momento chega na UNISC, quais os principais momentos dessa já longa experiência na Universidade, qual a avaliação que você faz dessa trajetória enquanto professor e gestor na Universidade?

\section{Marcos Moura Baptista dos Santos:}

Então. Eu cheguei na FISC (Faculdades Integradas de Santa Cruz) em agosto de 1986. As aulas já tinham iniciado e eu cheguei para substituir um professor de Sociologia, que saiu para trabalhar em outra Universidade. Então, eu entrei direto com um contrato de 40 horas, para trabalhar com disciplinas de Sociologia, de Antropologia e de Cultura Brasileira. Naquele semestre que aqui cheguei, no segundo semestre de 1986, terminava o mandato do Diretor Geral das Faculdades Integradas, que era indicado pela mantenedora, a APESC. Não havia eleições nem para a Direção-Geral, nem para as Faculdades. Eleição ocorria somente nos departamentos. O Diretor Geral era indicado pela mantenedora, e ele indicava os Diretores das Faculdades, que naquela época eram quatro: Administração, Contábeis e Economia; Direito; Educação Física; e Filosofia, Ciências e Letras.

Quando eu cheguei, a instituição estava vivendo o período de democratização do País. Era um período ainda muito próximo da Campanha pelas Diretas Já, da escolha do primeiro Presidente Civil. Naquele contexto, o DCE começou a ser organizado pelos estudantes. O presidente do DCE era o Bira, Ubiratan Trindade, da FFCL. E o DCE, após as suas eleições, pediu eleições na FISC para as direções das Faculdades. Em função disso, a Direção Geral tentou proibir o funcionamento do DCE, que convocou uma greve em protesto contra a tentativa de proibição do seu funcionamento. Muitos professores apoiaram a greve do DCE, em apoio à proposta de eleições na Instituição.

Então, eu chego aqui num tensionamento, e na minha primeira semana já tem uma assembleia de professores, com mais de cem pessoas. Eu percebi que havia um acirramento grande, e eu sem saber muito bem onde é que eu estou. Ocorreram duas assembleias, ainda em setembro daquele ano, e eu percebi que precisava escolher o meu lado naquele coletivo. E escolhi o lado da democratização.

Barbarói, Santa Cruz do Sul, n.59 - número especial, p.<113-154>, Ago./Set. 2021 
Aquele movimento foi vencedor e conseguimos aprovar as eleições para a Direção-Geral da Instituição e para as direções das faculdades. Lançamos uma chapa, que era composta pelo professor Wilson, para a Direção Geral, a professora Maria, para a direção da Filosofia, o professor Paulo Pinheiro Machado para a coordenação dos cursos de férias e o professor Luiz Augusto para Vice-Diretor Geral. Todos eles professores da FFCL.

Lembro que a administração pública municipal da época, que costumava indicar os membros do conselho superior da APESC, tentou impedir as eleições. Houve, inclusive, uma reunião muito tensa naquele período, que ocorreu no prédio do centro, na rua Oscar Jost. Inclusive, os estudantes colocaram carteiras para impedir a subida pelas escadarias, bloqueando o acesso às aulas. Só tinha como subir para a sala de aula passando pela escada e foi formada uma barricada de cadeiras. E ficou todo mundo no saguão. Foi naquele contexto da greve dos estudantes, com o apoio de professores, que se deu um ultimato para a Direção Geral; foi entregue um documento para a Direção e, bem, depois de muita negociação foi aprovada a eleição.

O professor Wilson concorreu contra o professor Edson, os dois pertencendo ao mesmo Departamento de Ciências. O professor Wilson ganhou as eleições e daí começou um novo período na instituição. Daí, em 1987, ocorreu eleição para chefia do Departamento de Ciências Sociais, que congregava a História, a Geografia, a Psicologia e as Ciências Sociais (Sociologia, Antropologia, Ciência Política). E, no mesmo ano, eu me candidatei para presidente da Associação dos Professores, nossa atual ADUNISC. Na época era APUVARP Associação dos Professores Universitários do Vale do Rio Pardo. Eu fiz um pequeno texto sobre minha compreensão do que era uma associação de classe, que foi publicado no jornal da Instituição, o Integração, e muitos começaram a dizer que eu tinha que assumir como chefe do Departamento. Então me candidatei para a chefia e, em 1988, assumi pela primeira vez uma chefia de Departamento.

Já naquele período havia um projeto de encaminhamento de uma consulta para o Conselho Federal de Educação - CFE, para a criação da Universidade. Mas foi um projeto que foi devolvido, pois ocorreram algumas mudanças nas regras do Conselho Federal de Educação. Era ainda durante o governo de José Sarney. Aquela Carta-Consulta foi devolvida, para ajustes às novas normas. Demorou um ano e, em 1990, se decidiu por um novo encaminhamento. O professor Wilson nomeou uma Comissão para isso. Quem assumiu a coordenação daquela comissão foi a professora Elizabeth (na época ela era superintendente de graduação, o equivalente a uma Pró-Reitora). Então, a professora Elizabeth coordenou aquela Comissão, que estava formada, além dela, pelo professor Thomé (na época ele era Superintendente de Administração), pelo professor Campis, Superintendente de Pesquisa e Extensão, pelo professor Wilson, por dois técnicos da Assessoria Técnica da Direção-Geral (o Roque e a Beatriz); e eu fui nomeado pelo professor Wilson para ser secretário daquela Comissão. Na verdade, minha função era redigir a Carta-Consulta, mas me deram liberdade para fazer o que eu achasse que deveria fazer, desde que a professora Elizabeth aprovasse depois.

A partir de então tivemos um longo trabalho coordenado por aquela Comissão e passamos a receber visitas de uma comissão de representantes do Conselho Nacional de Educação (novo

Barbarói, Santa Cruz do Sul, n.59 - número especial, p.<113-154>, Ago./Set. 2021 
nome do antigo CFE), formado por professores de Universidades Federais. Passamos dois anos, 1992 e 1993, com a Comissão, produzindo toda a documentação necessária e exigida para a solicitação de criação da Universidade.

E criamos uma ideia de universidade, que era uma universidade regional; aliás, uma ideia que o próprio Conselho Nacional na época defendia. Uma universidade focada nas necessidades da região, que iria oferecer cursos específicos para a região. E eles sugeriram que a gente pensasse cursos de graduação ligados à área do tabaco. Mas, também, sugeriram que a gente pensasse numa universidade da região dos Vales, que incorporasse o que na época era a FATES (Fundação do Alto Taquari de Ensino Superior) e a UNIVALI (que eu não lembro o que significava, mas que estava localizada em Cachoeira do Sul). Nós fizemos muitas conversas, até se avançou na possibilidade de trabalho com Cachoeira do Sul, mas nós avaliamos que não era uma alternativa adequada, porque consideramos que aquela região não tinha grande potencial econômico e nos interessava mais Lajeado e o Vale do Taquari. Mas, tanto aqui quanto lá em Lajeado, era considerado inviável pensar num projeto conjunto, pela histórica rivalidade regional. Onde vai ser a Sede, por exemplo? Essa discussão já encerrou a conversa. Então, a ideia de uma Universidade dos Vales foi por água abaixo, sem nenhuma chance.

\section{Entrevistadores:}

Naquele processo de construção da Carta-Consulta era a APESC a instância de elaboração?

\section{Marcos Moura Baptista dos Santos:}

Não. Só a FISC. Era a Comissão nomeada pelo Diretor-Geral e nós criamos, também, um grupo de discussão que envolvia os onze departamentos da época, que foi chamado de "grupo pensante". Um nome horroroso, mas enfim, compreendia os onze chefes de Departamento. E eu assumi a coordenação desse grupo.

\section{Entrevistadores:}

Ouvindo seu relato sobre aquele processo de encaminhamento da criação da Universidade pode-se perceber que ele foi conduzido, fundamentalmente, pela comunidade acadêmica, por professores e a gestão da FISC. E os setores externos à comunidade acadêmica? Participaram? Foram convidados para aquela discussão? Como ocorreram essas relações entre comunidade interna e externa à Universidade?

\section{Marcos Moura Baptista dos Santos:}

Não, não havia condições políticas para isso. Mas alguns acontecimentos são importantes. Por exemplo, nas eleições para a Direção-Geral nós, da chapa do professor Wilson, tivemos que ir ao Quartel (na época era o $18^{\circ} \mathrm{BIMtz}$ ), liderados pela professora Maria Kipper (vinculada a tradicional família santacruzense, filha de um ex-prefeito do município), para avalizar o nome do professor Campis, porque o comando do Quartel entendia que o professor Campis era um comunista e que não deveria estar na direção da faculdade. Então, a professora Maria foi lá

Barbarói, Santa Cruz do Sul, n.59 - número especial, p.<113-154>, Ago./Set. 2021 
apresentar o professor Campis, dizer que ele era uma "pessoa de bem". Ela, invocando o nome do ex-prefeito Edmundo Hope, pai dela. Então, a gente teve que chegar nesse ponto de contatos de bastidores. O professor Wilson era do diretório municipal do PDS de Venâncio Aires na época. Ele era do PDS, a antiga Arena. Além disso, nós tivemos conversas com lideranças políticas locais. Lembro de uma conversa com um vereador do PFL. Estávamos o professor Campis, o professor Valter Freitas e eu. E a primeira pergunta do vereador foi: "O senhor tem o seu título aqui?" E eu e o Valter respondemos: "não, votamos em Porto Alegre". E ele então falou para o Luiz Augusto: "Pois é, Campis, vocês não têm ninguém que traga voto para nós, por que é que eu vou me envolver com vocês? Então não, não tem o que eu possa fazer".

$\mathrm{Na}$ época, a gente pensava em uma coisa que seria uma lei municipal, a partir da qual a prefeitura colocasse um percentual do orçamento destinado à Universidade, para garantir bolsas para estudantes. Isso não foi adiante e ficou muito clara uma cisão entre a FISC e a cidade, o que vai aparecer em vários momentos. Tem um momento que, na minha avaliação, é emblemático. Foi quando o então vereador Sérgio Moraes, numa votação empatada na Câmara de Vereadores para decidir sobre a destinação de recursos do município para os estudantes, pediu vistas do processo, propôs uma reunião numa sala separada e voltaram de lá com uma decisão contrária aos estudantes. Os estudantes, na época representados pelo DCE, jogaram moedas nos vereadores quando eles passaram, saíram da sessão dizendo que eles tinham se vendido por merreca. Então, os estudantes jogavam moedas. A questão, diziam os vereadores, não era o dinheiro; mas na verdade era: "nós não vamos colocar dinheiro para esses 'comunistas' que estão assumindo a Universidade". Então, a faculdade ficou muito isolada do município, das chamadas forças vivas da região. Pelo menos essa é a minha leitura.

\section{Entrevistadores:}

Mas, ao mesmo tempo, havia a necessidade de relações políticas com representantes políticos da região como, por exemplo, lideranças estaduais e, mesmo, lideranças da região que tinham maior presença com o governo federal?

\section{Marcos Moura Baptista dos Santos:}

Sim. Tínhamos alguns contatos, em especial através do MDB. Inclusive tinha um professor que era vereador pelo MDB, o professor Ivo Weigelt. Ele tinha contatos com lideranças do partido no estado, com o André Foster, por exemplo, que era de Santa Cruz do Sul. Na época, o Foster era da direção estadual do MDB e tinha uma ligação com o professor Campis, também, amizade da juventude. Então, havia respaldo em lideranças do MDB. Por outro lado, lideranças do PDS eram contrários à ideia de ter uma Universidade. Não havia necessidade, diziam eles. Por que sentiam receio de perder controle político, eu penso que passava por isso. Mas, ao mesmo tempo, Lajeado fez um movimento também pela criação de uma Universidade. E aquele movimento acabou provocando um "bom, então vamos apostar em Santa Cruz do Sul". Mas eu penso que houve um descolamento muito grande entre a cidade e a faculdade por razões ideológicas.

Barbarói, Santa Cruz do Sul, n.59 - número especial, p.<113-154>, Ago./Set. 2021 
Mas voltemos à comissão. Naquele tempo, a gente trabalhava com a orientação da professora Elizabeth. E eu conversava muito com o professor Campis, que era do meu departamento, foi chefe do departamento antes de mim, tinha muito forte a ideia de Universidade com uma base na extensão. Porque na verdade é o que nós tínhamos. Nós tínhamos um setor de extensão, que tinha um trabalho bastante interessante, um trabalho ligado à igreja católica, através da irmã Delvina Pasquali, com boa inserção nas vilas populares da cidade. Tinha um trabalho de extensão interessante. Então, a ideia era isso, vamos criar uma universidade de extensão. E a pesquisa? Bom, era necessário ter pesquisa e extensão, mas o foco seria a extensão. E pela extensão a universidade seria um polo em desenvolvimento regional. A gente pensava que a extensão era o foco, porque a gente achava que pesquisa era uma coisa grande demais para nós naquele momento. Aqui em Santa Cruz, faculdades integradas, pequenas, com pouquíssima gente com titulação de doutor, pouca gente com titulação de mestre, nossa visão era essa: podíamos fazer um trabalho forte na extensão. E pela extensão, inclusive, a gente poderia chegar ao setor empresarial.

Mas, daí, percebemos que as indústrias fumageiras não tinham centros locais de decisão e que para elas não interessava a extensão. Ninguém era contra, mas a decisão toda era centralizada na matriz. A Souza Cruz, no caso, era no Rio de Janeiro, e era de lá que vinham as decisões de investimento. Então, o que a gente imaginava, o centro do tabaco, coisa assim, não fazia sentido para eles. Então, nós fomos descobrindo como é que se fazia universidade. Na verdade, tinha o Campis, a Maria, o Wilson, que conheciam bem a região; mas, ainda tinha aquela dúvida acerca de como é que se faz uma universidade.

Então, os documentos da Universidade, que foram produzidos naquela época, todos eles expressam essas apostas na extensão. Uma Universidade voltada para o desenvolvimento regional, uma universidade regional baseada na extensão. Por conta disso, se falava muito na comunidade. Então, nós, em determinado momento, quando percebemos que não daria certo o projeto de integração com Lajeado e nem com Cachoeira do Sul, paramos de trabalhar com a ideia de uma Universidade regional e passamos a trabalhar com a ideia de uma Universidade Comunitária.

Eu, na época, por conta das coisas que eu andava lendo sobre o público não estatal, insisti inúmeras vezes para que essa fosse a linguagem. Mas a linguagem não era essa, era a linguagem da Universidade Comunitária, que se vinculava com a tradição, que eu até então não conhecia, das universidades de integração regional, como o exemplo da UNIJUÍ. A própria UFSM, que antes de ser federal também discutiu essa questão de integração regional, passou a ter diversos campi na sua região, nas missões, na região noroeste do estado. Então, nós trabalhamos com isso, uma universidade comunitária que poderia ser uma universidade de integração regional.

Mas o comunitário não tinha naquela época a conotação que tem hoje, de um público não estatal, numa tentativa, inclusive, de receber recursos públicos mesmo não sendo estatal. Então, o foco era muito mais isso: "a gente precisa de recurso público, senão a gente não consegue ir adiante”. Penso que isso era até uma espécie de dilema ideológico. Como é que a gente dá conta daquela consigna tão importante, do Florestan Fernandes, "dinheiro público para escola pública”, quando a gente não era uma escola pública, mas queria dinheiro público.

Barbarói, Santa Cruz do Sul, n.59 - número especial, p.<113-154>, Ago./Set. 2021 
E daí a definição: "não, nós somos públicos; o que nós não somos é estatal”. Bom, no meio do caminho, nos demos conta de que seria muito difícil explicar tudo isso para as pessoas. A diferença do estatal para o não-estatal, do público para o não-público. E fortalecemos o discurso do comunitário.

E aconteceu, tinha acontecido no final dos anos 1960, e depois tinha sido retomada no início dos 1980, a tentativa de federalização da UCS. A UCS, em 1967, fez o primeiro movimento para se transformar em Universidade. E o projeto era se transformar em universidade federal. E, então, surgiu aqui a ideia de, já que vai ter uma universidade aqui e ela vai ser pública, ela não vai cobrar mensalidade.

Então, começou um outro discurso, o discurso comunitário, ser da comunidade. Não é nem federal, nem pública: é comunitária. Que é o que depois o João Pedro desenvolveu, inclusive como pró-reitor, mais recentemente, e conseguiu, inclusive, ser um dos importantes articuladores do marco legal das instituições comunitárias.

Mas isso, na época, não era nosso horizonte. Nosso horizonte era, de alguma maneira, acessar recursos públicos para criar uma Universidade. Então, nós trabalhávamos com essa ideia. Sabíamos fazer extensão, a Universidade precisava disso, para fazer extensão não era necessário curso stricto sensu, nós víamos que o stricto sensu era muito difícil. Então, quando surge a ideia, a necessidade, tem que ser universidade, tem que ter stricto sensu, foi uma coisa que nos assustou muito. Era um medo grande disso. Vejam, nosso primeiro Programa de Pós-Graduação, em desenvolvimento regional, foi em 1994, quando contratamos o professor Denizar para fazer o projeto, com a articulação que ele já tinha acumulado em seu doutorado em Economia na Unicamp. Então, a força toda entre 1991 e 1994 era pela extensão. E aí tinha uma moda, na época, das agências do desenvolvimento regional, durante o governo estadual de Collares, a proposta de ter agências de desenvolvimento. A discussão chegou aqui, com a ideia de criação de uma agência regional de desenvolvimento, de a nova universidade ser uma agência de desenvolvimento regional.

\section{Entrevistadores:}

\section{Interna na universidade?}

\section{Marcos Moura Baptista dos Santos:}

Interna. Nessas conversas nós recebemos informações de que tinha espaço para criar pólos regionais de modernização tecnológica. E esse foi o investimento que foi feito, através de contatos com a Secretaria de Ciência e Tecnologia (não sei se o nome era exatamente esse na época). E já existiam os COREDES - Conselhos Regionais de Desenvolvimento, que foram importantes para a criação do Polo. Vieram recursos para a construção do bloco 11. Esse bloco foi um resultado desta ideia da universidade regional, comprometida com o desenvolvimento regional através da modernização tecnológica.

No primeiro período, então, basicamente a ideia era essa. E nós queríamos trazer uma discussão sobre o que é região: o que se pretende falar com universidade regional? Se quer falar de regional, então é preciso saber o que é região. E a UCS tinha um documento muito

Barbarói, Santa Cruz do Sul, n.59 - número especial, p.<113-154>, Ago./Set. 2021 
bom, definindo "região" como um conjunto de municípios articulados por uma memória e uma cultura comuns, e por uma malha rodoviária, que permitia a comunicação. E nós pensamos na mesma coisa aqui, pois nos demos conta que, na verdade, história e cultura comuns definiam o Vale do Rio Pardo. Então, a gente ficou no Vale do Rio Pardo. Tanto que, na época, a associação dos professores se chamava Associação dos Professores Universitários do Vale do Rio Pardo; e nós chegamos a pensar em ser Universidade do Vale do Rio Pardo. Num primeiro momento se pensou nisso, depois ficou Universidade de Santa Cruz do Sul.

\section{Entrevistadores:}

Mas chegou a acontecer uma discussão formal sobre essa possibilidade?

\section{Marcos Moura Baptista dos Santos:}

Sobre o nome? Sim, chegou. Se seria o melhor nome. Foi uma discussão interna na universidade, no momento em que estávamos redigindo o projeto, com os três membros do Conselho Nacional de Educação, que estavam aqui. Eles falavam: "vamos manter Vale do Rio Pardo"; e internamente se achava que a cidade não ia gostar, que a cidade não compraria a ideia. Para a população e o empresariado locais, Santa Cruz do Sul era mais importante do que o Vale do Rio Pardo. Então, o nome ficou UNISC, por entender que "pegaria melhor na cidade".

\section{Entrevistadores:}

E já tinha a FISC também, que era uma indicação de ensino superior de Santa Cruz do Sul.

\section{Marcos Moura Baptista dos Santos:}

Já tinha a FISC, Faculdades Integradas de Santa Cruz. E a ideia foi essa, de considerar que o município era o mais importante da região e que a Universidade, mesmo sendo de Santa Cruz do Sul, teria uma importância para toda a região. Mas a discussão sobre "região" não avançou. Não é que não avançou: ela ganhou um lugar na Universidade. Onde é que ela ficou? No que a gente chamava de Mestrado, no Mestrado em Desenvolvimento Regional. Foi ali que a discussão teve continuidade.

\section{Entrevistadores:}

Ouvindo seu relato pode-se dizer que mais importante do que a discussão interna sobre o regional e sobre Universidade Regional era, naquele momento, o debate que se estabelecia sobre o regional no Rio Grande do Sul? Foi um momento de discussão dos Conselhos Regionais, o próprio governo estadual impulsionou esse debate, você também faz referência a uma discussão existente na Universidade de Caxias.

\section{Marcos Moura Baptista dos Santos:}

Sim, sem dúvida nenhuma. Era o caminho que se mostrava. Naquele período foi construída a URI - Universidade Regional Integrada, resultado de uma integração de diferentes faculdades,

Barbarói, Santa Cruz do Sul, n.59 - número especial, p.<113-154>, Ago./Set. 2021 
localizadas em Santo Ângelo, Erechim, Frederico Westphalen. Quer dizer, uma superação das vaidades das cidades, pois eles até organizaram a Reitoria de modo itinerante: ficava um tempo em Santo Ângelo, um tempo em Erechim. Acho que agora está só em Erechim. E tinha a URCAMP, Universidade da Região da Campanha. Mas, por outro lado, tinha a UNIJUÍ (UNIJUÍ era a sigla), um nome que indicava a importância da cidade, mas de uma Universidade com projeto regional, pois inclusive a FIDENE, mantenedora da UNIJUÍ, significa Fundação Integrada de Desenvolvimento do Noroeste do Estado.

Então, o que existia era uma preocupação com a região. Era essa a ideia. A URCAMP, a URI, nós queríamos aqui também uma regional, uma regional do centro do estado. Era essa a ideia. Mas não havia acúmulo de discussão sobre região, nem sobre integração regional. Tanto que, se olharmos o texto que estava escrito na carta encaminhada para o Conselho Nacional, vamos encontrar algo assim: "a UNISC é uma universidade de pequeno porte, que atende de maneira qualificada às necessidades culturais, educacionais e de desenvolvimento científico e tecnológico da região de Santa Cruz do Sul, em virtude das demandas regionais, estendendo a sua influência pelos Vales do Rio Pardo, Taquari e Jacuí". Mas, na verdade, era a região de Santa Cruz do Sul, que era apresentada como a capital do fumo, principal núcleo de colonização alemã. Então, era a cidade de Santa Cruz que era apresentada como a força da universidade. O regional foi ganhando importância, inclusive por que os pareceres indicavam que se chamasse de regional, para facilitar a aprovação. Esse tinha sido o caso da URCAMP, o caso da URI. Então, na Instituição, nas Faculdades Integradas, não havia discussão de região. Nenhuma discussão de região. Isso só vai acontecer a partir do programa de mestrado em desenvolvimento regional. Na minha leitura foi isso que ocorreu.

\section{Entrevistadores:}

Vamos aproveitar essa contextualização sua sobre o periodo de criação da UNISC para colocar a questão das humanidades nessa experiência universitária. No seu relato, fica claro que já existia um departamento que congregava áreas das humanidades, além de outros departamentos, vinculados às diferentes áreas do conhecimento. Mas também havia a discussão política, tanto interna quanto na cidade. Inclusive a identificação de determinados professores, vinculados esses com as humanidades, como militantes em campos politicos opostos a lideranças locais. Qual a avaliação que você faz sobre o espaço das humanidades naquele contexto de criação da UNISC?

\section{Marcos Moura Baptista dos Santos:}

Veja, a gente tinha a Faculdade de Filosofia, Ciências e Letras, que foi a segunda faculdade de Santa Cruz do Sul (a primeira foi a FACOSUL, que compreendia as Ciências Contábeis, as Ciências Econômicas e a Administração de Empresas e foi criada ainda no início da década de 1960). Então, a Filosofia era uma faculdade. Aí foi criada a Faculdade de Direito, como extensão da UFSM. Depois foi criada a Escola Superior de Educação Física, como extensão da UFRGS. E a Faculdade de Filosofia, Ciências e Letras logo foi a que mais teve alunos, porque tinha os cursos de licenciatura, que na época eram muito fortes. E também tinham os cursos de férias, cursos voltados à formação de professores durante o período de férias. Então,

Barbarói, Santa Cruz do Sul, n.59 - número especial, p.<113-154>, Ago./Set. 2021 
a Filosofia era a maior faculdade, com mais alunos, com mais professores. E tinha um nome clássico, Faculdade de Filosofia, Ciências e Letras, que era o modelo das faculdades de Filosofia que tinha por aí..

A Faculdade de Filosofia, no momento em que eu chego a Santa Cruz, compreendia quatro departamentos: o departamento de Ciências, que envolvia matemática, biologia, química, física; o departamento de Ciências Sociais, que eu já detalhei; o departamento de Letras; e o departamento de Educação. Eram esses quatro departamentos. Então, veja: Educação, Letras, Ciências Sociais e Ciências. E tinha o maior número de professores e o maior número de cursos: cursos de moral e cívica, curso de estudos sociais, curso de letras, curso de pedagogia, cursos de férias em todas essas habilitações. E todos esses cursos eram muito fortes.

Além disso, nós das Ciências Sociais tínhamos disciplinas em todos os cursos. Eu dava aula, quando eu cheguei, de Antropologia, de Cultura Brasileira, de Sociologia em diversos cursos. Tinha até Cultura Religiosa, que também era dada pela gente, era uma disciplina da área das humanas.

Mas tinha um enfrentamento grande com as demais faculdades. E aí o que tinha era que algumas pessoas da cidade, volto a falar na professora Maria Kipper, da História, na professora Elizabeth Rizzato Lara, da Letras, elas eram pessoas da cidade, pessoas da "sociedade". E a professora Helga Haas, na educação. Então, eram pessoas de famílias com sobrenomes importantes. E, então, havia um respeito com essas pessoas, e eu acho que esse respeito chegava às humanidades. E nós fomos trabalhando com isso. Então, nós fomos construindo e fortalecendo esse departamento de Ciências Sociais, que foi dissolvido em 1991, no processo de criação da Universidade.

Em 1991, quando a nossa carta-consulta foi aceita pelo Conselho Nacional, nós iniciamos dois anos de acompanhamento, uma espécie de tutela pela comissão do CNE. Ao contrário de várias Universidades, que eram autorizadas e depois reconhecidas, nós não fomos autorizados, nós vivemos uma transição em acompanhamento, para que a estrutura fosse paulatinamente transformada. Foi somente em 1993 que ocorreu o reconhecimento. Em julho de 1993, a UNISC foi reconhecida como Universidade. Foi a primeira Universidade brasileira que não precisou ter autorização e já passou a operar com plena autonomia. Naqueles dois anos nós modificamos a estrutura organizacional, para que ela se aproximasse de uma “estrutura universitária". E, por isso, em 1991 nós extinguimos as Faculdades e criamos os Departamentos. E foi lá que, então, foi criado o Departamento de Filosofia, Psicologia e Sociologia. Era esse o nome do Departamento. História e Geografia se separaram, criaram outro departamento. Ocorreu o mesmo com Letras e com a Educação. E nós ficamos com a Psicologia, Filosofia e a Sociologia, que abrangia também a Ciência Política e a Antropologia.

\section{Entrevistadores:}

Já como um modelo do que viria a ser o Departamento de Ciências Humanas?

\section{Marcos Moura Baptista dos Santos:}

Barbarói, Santa Cruz do Sul, n.59 - número especial, p.<113-154>, Ago./Set. 2021 
Sim, só o nome não era esse. O nome oficial era Filosofia, Psicologia e Sociologia, em ordem alfabética, inclusive. Só vai ser Ciências Humanas em 1993. Aliás, foi naquele ano de 1993 que a Barbarói foi criada, já no Departamento de Ciências Humanas que, naquela época, ainda incorporava os colegas da Psicologia. E o número zero da Barbarói foi justamente uma edição temática, um dossiê sobre a Universidade. Importante registrar que o Departamento de Ciências Humanas, desde que surgiu, começou a sofrer um desgaste no sentido da retirada de disciplinas. Então, primeiro começou um movimento de diminuição da disciplina de Métodos e Técnicas de Pesquisa. Em alguns cursos tinha metodologia científica e MTP; entendida a metodologia científica como teoria da ciência, como epistemologia. E MTP compreendendo a parte mais instrumental. E começou lá o corte, ficando somente uma, a MTP. Depois, essa mesma disciplina passou de 60 horas para 30 horas. As disciplinas sobre realidade brasileira passaram a ser transformadas também e, aos poucos, passaram de 60 para 30 horas. Alguns cursos, inclusive, simplesmente tiraram a disciplina. E, naquele momento, na verdade, nós vivíamos uma contradição, pois até então, ainda na condição de estudantes, cobrávamos que as disciplinas de EPB, depois Realidade Brasileira, não fossem obrigatórias (eram disciplinas de doutrinação criadas pela ditadura); mas, a partir de então, já como professores, passamos a lutar pela obrigatoriedade dessas disciplinas. Mas, é claro, já naquelas alturas a cobrança pela obrigatoriedade dessas disciplinas era porque havíamos modificado os conteúdos e percebíamos que a formação sociopolítica, humana, estava cada vez mais reduzida; e poderia ser complementada com essas disciplinas.

Lembro que participei de reuniões, junto com o João Pedro, com diferentes cursos, para a manutenção de disciplinas. Então, começou a ter diminuição lá ainda. Tem um momento em que cursos que tinham sociologia e antropologia tiraram uma. Depois, essas disciplinas passaram a ter 30 horas. Teve um determinado momento em que o discurso passou a ser favorável para disciplinas específicas: sociologia da saúde, sociologia do esporte, sociologia do direito. Num primeiro momento era colocado: “ah, porque daí fica mais específico; senão não há sentido de ter a disciplina, se for específica fica mais útil”. Mas, num segundo momento, a gente se deu conta que era o caminho para que nossas disciplinas pudessem ser dadas pelos professores do próprio curso. Então, um advogado passou a dar sociologia do direito. Nós tivemos vários embates na época, no CONEPE (Conselho de Ensino, Pesquisa e Extensão), eu pelo Departamento de Filosofia, Psicologia e Sociologia, e o professor Rudimar Serpa, pelo Departamento de Direito. E nós perdemos essa discussão, com o conselho sendo favorável à ideia de que sociologia do direito era uma disciplina da área do direito. Mesmo com toda argumentação, na hora de votar a ampla maioria ficou favorável à sociologia do direito como disciplina do direito. Depois tentaram colocar a Sociologia Aplicada à Administração no departamento de Administração. E isso só não ocorreu porque na época o professor Edgar Hoffman, que foi o professor indicado para trabalhar na disciplina, disse: "eu só vou dar Sociologia aí se essa disciplina for do meu departamento". O Edgar era uma reserva moral das faculdades integradas, era respeitado pelas outras áreas, tinha um mestrado em Filosofia e um doutorado em Teologia, cursado no Vaticano. Quando ele disse aquilo (naquele momento somente ele e outro professor trabalhavam com sociologia), mesmo o outro professor, que era vinculado à Administração, veio para o nosso departamento para continuar trabalhando com a disciplina. Não fosse aquilo, então, talvez nunca teríamos tido a

Barbarói, Santa Cruz do Sul, n.59 - número especial, p.<113-154>, Ago./Set. 2021 
disciplina de Sociologia do Trabalho no curso de Administração. Ou teríamos, mas vinculada ao próprio curso. Então, desde o início as humanidades nunca tiveram facilidade. Só que, como sabemos, naquela época tínhamos bastante disciplinas e aos poucos foi tudo diminuindo. E isso segue até hoje, embora hoje as humanidades também compreendam letras, psicologia, cultura.

\section{Entrevistadores:}

Aproveitando essa discussão sobre as próprias dificuldades encontradas para manter disciplinas e as históricas decisões que reduzem a carga horária das disciplinas de sociologia, antropologia, filosofia. É uma questão relacionada à falta de uma política de graduação, capaz de definir com maior clareza os parâmetros curriculares dos diferentes cursos e, nesses espaços, para a formação humana? Agora, por exemplo, embora se possa fazer críticas ao projeto "reinvenção", a questão é que a Reitoria chamou para ela o compromisso, mas também a prerrogativa, de definir parte da formação, a partir de um conjunto de pressupostos que afirmam uma concepção de formação universitária. Os cursos serão organizados a partir desses parâmetros. Então, nossa história é marcada por uma ausência dessa definição? A autonomia dada aos cursos pode ser lida como uma dificuldade de definição de uma política de graduação na e da UNISC?

\section{Marcos Moura Baptista dos Santos:}

$\mathrm{Eu}$ penso que é a primeira vez que isso está acontecendo. Eu, particularmente, tenho a memória de inúmeras reclamações de que a PROGRAD não tinha política pedagógica, que não tinha política de formação. Que faltava uma política de formação e que ela tinha que vir da Reitoria. Quando eu estive na Reitoria, como pró-reitor de planejamento, eu coloquei isso. E havia uma resistência muito grande, a partir do pressuposto de que a reitoria iria impor definições aos cursos. E a gente dizia: "não, nós estamos propondo o debate". E a compreensão era de que se tratava de uma imposição. E havia resistência. E nunca se conseguiu fazer uma proposta mais acabada de política pedagógica. Se a gente olhar os documentos da época, até tem isso, mas isso é um voluntarismo que sai daquela comissão

encarregada de fazer, não é nem o debate dos onze que formavam o "grupo pensante". É uma discussão muito fechada. Se olhar os documentos, até é possível encontrar algo numa ou noutra passagem, mas era uma ideia que não tinha muita consistência.

Era um trabalho mais ilustrado, esse da comissão de transformação da FISC em UNISC. Nós tínhamos como referência, por exemplo, a PUC de São Paulo, a democratização da PUC de São Paulo nos anos 80. Então, a gente trabalhava muito, eu e a Elizabeth, com textos que vinham da PUC de São Paulo. E nos documentos da PUC de São Paulo, na época, se encontrava algo do tipo: "nós somos uma universidade católica, e nós estamos chamando a comunidade católica para que diga o que a comunidade católica quer da sua universidade". E nós temos esta redação aqui, tirando o católico, que nós vamos chamar a comunidade de Santa Cruz para dizer o que quer da sua universidade. Mas isto era muito mais nosso, assim. Aí o que a gente fez? A gente fez questionários, distribuiu coisas para as pessoas responderem, pegamos as entidades, as empresas, perguntamos o que queriam, fizemos um caminho.

Barbarói, Santa Cruz do Sul, n.59 - número especial, p.<113-154>, Ago./Set. 2021 
O professor Wilson, por exemplo, organizou caravanas da FISC nos municípios. O que Rio Pardo quer? Ele quer curso aqui. O que Sobradinho quer? A gente quer curso aqui. O que Venâncio quer? O que Candelária quer? A gente foi mapeando a região, a gente foi em todas as cidades. Todas as cidades pediam cursos ali. E aí nós tomamos a decisão de fazer em Sobradinho, e só em Sobradinho. O primeiro campus fora de sede foi o de Sobradinho. O que tem sentido, pensando em desenvolver a região. Depois foi o de Venâncio Aires, que sempre foi visto apenas como um "fechar as portas para as instituições do Vale do Taquari que estão entrando aqui". Nunca foi pensado "num projeto para Venâncio Aires"; era "fechar a porta", proteger o território. Depois surgiu a ideia de (no meu entendimento algo meio absurdo) Capão da Canoa. Olha que eu participei ativamente das tratativas com a prefeitura de Capão. Mas, desde o início, também era uma coisa sem nenhum sentido, que era o enfrentamento com a ULBRA: "vamos enfrentar a ULBRA", esse era o norte. Sendo a ULBRA considerada nossa grande concorrente, a gente pretendia fechar todas as portas da ULBRA. Não conseguimos fechar nem em Cachoeira, quando a gente tentou ir pra Cachoeira a ULBRA já estava lá. E aí, então, a ULBRA estava em todas as regiões e a gente foi para Capão. Quer dizer, não tem nada a ver com a região, com a nossa região, não faz o mínimo sentido, mas era isso.

E, é claro, havia a expectativa de ganhos financeiros. Por que, na verdade, a gente pensava em Porto Alegre, entrar na região metropolitana. Nós conversamos com Triunfo. Eu que fiz essa conversa. O município até nos ofereceu um prédio pronto. Mas nós ficamos desconfiados, na época, das condições que a prefeitura colocava, e ficamos com medo de nos envolvermos num negócio complicado, que poderia resultar em tribunal de contas, e não fomos para Triunfo. Que é um município forte economicamente, tinha dinheiro, por causa dos impostos do polo petroquímico. Depois fomos para Montenegro. Montenegro está perto de Porto Alegre também. E tinha uma ideia de que a gente ia entrar com pólo em Porto Alegre, que poderíamos fazer um convênio com o Esporte Clube Internacional, para entrar em Porto Alegre. E todos esses movimentos foram muito questionáveis se considerarmos seus resultados e o que de fato funcionou.

Mas, então, na nossa região, Venâncio Aires, nós nunca pensamos num projeto para Venâncio Aires. Sobradinho, desde o início, a gente sabia que não tinha muito o que crescer. Mas era uma coisa que a gente tinha muito claro, desde o início. Esse projeto é que nem bicicleta, ele só não vai cair se a gente não parar de pedalar. E pedalar significa colocar um ou dois cursos novos por ano. E não dá para colocar tudo em Santa Cruz, porque custa dinheiro, porque tem que ter laboratório, porque é curso sem muito nome etc. Mas, em Sobradinho, dá para colocar Direito e Administração, é só biblioteca que precisa, um prédio e biblioteca. Cursos que, na época, tinham uma procura muito grande. Então, a gente colocou Direito, Administração e Contábeis. Era Direito, Administração e Contábeis depois em Capão, em todos os lugares, era por aí que a gente começava.

\section{Entrevistadores:}

Barbarói, Santa Cruz do Sul, n.59 - número especial, p.<113-154>, Ago./Set. 2021 
Mas, então, no seu entendimento, a UNISC nunca teve um projeto global de expansão? Pelo menos nunca houve clareza quanto a esse projeto!?

\section{Marcos Moura Baptista dos Santos:}

$\mathrm{Eu}$ penso isso. Eu penso que quando a gente estava, quando eu estava na PROPLAN, eu lembro que a gente chegava a discutir tamanho, nós queríamos ter 10 a 12 mil alunos. Era isso. Nós tínhamos uma discussão, inclusive, se isso era pequeno ou médio porte. Alguns chamavam de pequeno porte. Então, nós queríamos chegar aos 12 mil alunos. E, para isso, a gente precisava criar mais cursos, para chegar aos 12 mil alunos. Um número que, entendíamos, manteria a Universidade funcionando, permitiria contratar mais professores, facilitaria a criação de mestrados, doutorados, poderia bancar todo o funcionamento com este número. E que foi o nosso número máximo. Em 2014, por exemplo, nós tínhamos em torno disso, entre 10 e 12 mil estudantes. E nós tínhamos três mil alunos em 1993. Então, a ideia era quadruplicar nosso tamanho. E isso, sim, era o projeto que estava nos PDIs. Se a gente pegar os PDIs, a gente vê que tem muito maior preocupação com número, com tamanho, com cursos, do que com qualquer discussão de pesquisa, de ensino. Projeto político pedagógico é uma coisa bem mais recente.

\section{Entrevistadores:}

Podemos retomar isso. Mas vamos aproveitar um pouco essa reconstrução de sua trajetória no Departamento para entender melhor como ocorreu a criação da Barbarói. Quem levantou a discussão? O que se pretendia naquele momento com a criação da Revista? Estava dentro de uma politica institucional ou resultou do interesse de professores do Departamento?

\section{Marcos Moura Baptista dos Santos}

A instituição já tinha várias revistas, né. Tinha a revista da Letras, tinha a revista da Educação, tinha a revista da Química. Não era exatamente um perfil de revista científica, mas tinha. No departamento, na época de Filosofia, Psicologia e Sociologia, a gente tinha o grupo de maior número de professores com mestrado, muitos com os doutorados em andamento. E muitos faziam mestrado e doutorado nas federais, e já tinham feito graduação nas federais. Nesse sentido, pensavam muito a partir de uma ideia de universidade como a universidade federal. $\mathrm{E}$ esses professores é que insistiram: "nosso departamento também tem que ter uma revista; só que a nossa revista vai ser uma revista acadêmica, vai ser uma revista científica, vai ser uma revista de universidade". E essa era a ideia. E aí teve muito trabalho desses colegas. Eu lembro o professor Nilton, que era da Antropologia, fazia doutorado na UFRGS; lembro do professor Éber, que era da Sociologia e que fazia o doutorado em Planejamento Urbano no PROPUR da UFRGS. Foram eles que fizeram contatos para montar um conselho editorial. Que na época tinha professores como, por exemplo, o José Vicente Tavares, o Pedro Demo. O Pedro Demo chegou a palestrar aqui, nós o trouxemos para uma aula inaugural e aproveitamos para incorporá-lo no conselho editorial.

Então, buscamos através destes contatos montar um conselho editorial forte. Nosso conselho editorial chegou a ter muitos nomes importantes. Nomes que depois foram sendo tirados,

Barbarói, Santa Cruz do Sul, n.59 - número especial, p.<113-154>, Ago./Set. 2021 
porque simplesmente esse conselho editorial era para nós, na época, com a expectativa de que eles poderiam nos dar pareceres sobre artigos da revista. Mas, na verdade, nunca tinham tempo. Nunca veio um retorno do Pedro Demo dos pareceres que a gente pediu para ele. Ou do Zé Vicente. E a gente se deu conta que esse conselho editorial não era para o dia-a-dia, como a gente achava que seria. E aí que fomos nos tocar que a revista era por nossa conta. $\mathrm{E}$ aí depois até foi se alterando, tentando fazer uma coisa mais viável, editar a revista e tudo.

Mas, então, a revista surgiu como uma necessidade dos professores do departamento. Eu lembro que no primeiro número da revista foi dito: "olha, é uma revista que vai ter sempre um ou dois artigos endógenos, e o resto vem tudo de fora, e esse de fora são os nossos contatos que vão fazer, e o conselho editorial que vai trazer, a não ser o número zero, que vai ser todo de dentro". Mesmo assim, teve um artigo do José Vicente no número zero, que é um artigo mais geral sobre universidade. Aí eu penso que a Barbarói chegou a propor através do nosso departamento a ideia de fazer um debate sobre o que é ser uma universidade. Mas que não tinha repercussão, não havia essa preocupação no restante da instituição. Eu lembro de uma fala do professor João Maria, do Direito, ele dizia o seguinte: "ah, essa discussão só pega para quem está fazendo doutorado fora". Como ele estava fazendo doutorado né: "Então essa discussão interessa só para nós, fora disso não vai rolar, não vai acontecer, nem percam tempo". E foi isso que aconteceu. Então, a Barbarói surgiu como uma necessidade dos professores do departamento, de colocar a sua produção. Alguns, com certeza, faziam doutorado pensando "eu preciso de currículo e eu não vou conseguir publicar na revista lá na UFRGS, eu vou publicar aqui". Mas logo a gente se deu conta que a endogenia era um problema para a revista, então não podia publicar os nossos aqui. A gente chegou a publicar alguns artigos nos primeiros números, artigos de alunos das faculdades, depois também já foram retirados, porque não daria certo. Eu não sei quando é que a gente começou a se preocupar com Qualis, mas a partir daí a revista tomou outras direções.

\section{Entrevistadores:}

Em relação a Barbarói também é importante registrar que ela passou a ser editada em conjunto com os colegas da Psicologia, quando a Psicologia passou a ser um Departamento. Depois de um tempo, no entanto, nossos acordos não conseguiram segurar a parceria.

\section{Marcos Moura Baptista dos Santos:}

$\mathrm{Na}$ verdade, a ideia deles, a partir da criação do Mestrado profissional em Psicologia, a ideia era de que eles assumissem a Barbarói sozinhos, uma revista que já estava consolidada, já tinha Qualis. Então, quer dizer, antes de lançar uma revista nova, com o horizonte do mestrado já colocado, a ideia deles é que a Barbarói fosse deles. Mas eu acho que o grande problema foi esse, o da editoração. Eu lembro, eu fui editor da Barbarói em conjunto com a professora Silvia Aerosa. E nós tivemos dificuldade muito grande em trabalhar juntos. Muito grande. Uma relação sempre muito cordial, mas sempre muito difícil. E, antes disso, eu já tinha assumido a coordenação em conjunto com ela, porque os colegas aqui diziam que, em conjunto, não assumiriam mais, então já tinha dado problema antes. Então, teve uma sucessão aí de editores da revista. E acho que a editoração conjunta depois de mim, quando eu saí, acho

Barbarói, Santa Cruz do Sul, n.59 - número especial, p.<113-154>, Ago./Set. 2021 
que ainda alguém assumiu em conjunto com outro colega da Psicologia. Mas, no início, a gente ficou juntos e quando ocorreu a separação dos departamentos, era mais ou menos tranquilo que a revista era dos dois, a gente ia trabalhar juntos. Mas era uma ideia meio ingênua, de que a coisa era muito pequena, depois que vimos que não era bem assim.

\section{Entrevistadores:}

Mas, para retomar o inicio de seu relato, sobre sua trajetória na UNISC. Pode-se dizer que uma primeira fase de sua participação ocorreu no período de criação da Universidade e que uma segunda fase ocorreu quando você, enquanto participante da Reitoria, assumiu a Pró-Reitoria? Ou, na sua avaliação, essa trajetória tem outros momentos?

\section{Marcos Moura Baptista dos Santos:}

Sim. Teve. Primeiro, houve um período em que eu fiquei responsável pela redação dos documentos, que vão gerar o projeto de reconhecimento. Em função do trabalho com a Elizabeth, a Elizabeth era uma pessoa muito importante na universidade, muito reconhecida. Ela, por vontade do professor Wilson, seria a vice-reitora, e não o Campis. Ela, e não a Helga. Nós tivemos um embate político, e tivemos uma reunião muito áspera, muito áspera, em que o Campis e a Helga foram dizer para o Wilson: "não é tu quem escolhe, nós temos um grupo, e se tu quiseres bancar, tu estarás sozinho". E ele percebeu, e ele recuou, recuou. Então, a Elizabeth era alguém muito importante na instituição. E a partir da experiência na comissão pró-universidade, a Elizabeth me chamou para trabalhar com ela, depois que nós já éramos universidade, para criar o programa de avaliação institucional. Naquela época havia sido instituído o PAIUB (Programa de Avaliação Institucional das Universidades Brasileiras) e havia recursos, havia recursos para universidades privadas sem fins lucrativos, e a gente precisava escrever um projeto de avaliação institucional. Então, eu escrevi o programa de avaliação da UNISC. A Elizabeth pegou esse programa, melhorou, e pelas relações políticas dela e do Wilson, transformaram ele em Programa do COMUNG, o PAIUNG (Programa de Avaliação Institucional da Universidade do COMUNG). Foi feito por nós aqui, eu redigi, a Elizabeth revisou, organizou melhor, colocou o que era preciso colocar, e ela e o Wilson aprovaram isso no COMUNG. Então, a UNISC passou a coordenar a avaliação institucional do COMUNG. A Elizabeth foi a primeira coordenadora de avaliação institucional. E eu estava ali com ela, dois ou três anos, 94 a 96, fazendo isso. Depois, o Carlos Aires vai ser o coordenador da avaliação institucional do Comung. Sempre era a UNISC que coordenava essa avaliação. E aí, sai disto, 96, 97, já que funcionou o programa de avaliação, vamos criar universidade virtual. E em 99, eu já era pró-reitor, nós criamos um grupo de trabalho para criar a universidade virtual comunitária do Rio Grande do Sul. Eu era o vice-coordenador, com um colega da UCS na coordenação. Depois a Elizabeth assumiu a coordenação e um colega da URI, de Santo Ângelo, assumiu a vice-coordenação. Então, eu tive um trabalho muito atrelado ao trabalho da professora Elizabeth, embora nunca tivesse nenhum cargo, a não ser chefia de departamento.

Eu era chefe de departamento. Era meu cargo institucional, mas eu trabalhava no entorno da Reitoria. Então, a gente redigiu projeto de uma universidade virtual, baseada em satélites,

Barbarói, Santa Cruz do Sul, n.59 - número especial, p.<113-154>, Ago./Set. 2021 
transmissão por satélite. Tecnologicamente ficou defasado, quando a gente estava com o projeto pronto, não fazia mais sentido usar a tecnologia de transmissão por satélites. Por conta desse projeto, a universidade me mandou para o México, visitar o ITESM, Instituto Tecnológico de Monterrey, que tinha uma universidade virtual por satélite. Fomos, eu pela UNISC, o na época senador Chiarelli pela UCS, Jaime Giollo, na época pró-reitor de extensão da UPF (que já no século XXI se tornaria reitor da UFFS). Fomos lá, para conhecer esse projeto, e voltamos de lá, eu apavorado com o projeto capitalista do Tecnológico de Monterrey; mas, ao mesmo tempo, fascinado com a tecnologia deles. A UCS percebeu logo que não fazia mais sentido e caiu fora. A FEEVALE chegou a alugar satélite, e saiu fora do projeto conjunto. E aí as outras brigaram por vaidade, nós, URI, UPF, UNIJUÍ, e a UCERGS, Universidade Virtual das Comunitárias do Rio Grande do Sul, terminou aí.

Em 1994, ainda, eu fui assessor de planejamento do reitor. O reitor era o Wilson, eu tinha 10 horas semanais pagas "para pensar". O Wilson me disse: "Tu pensa, tu me entrega as coisas e eu vejo se eu jogo fora ou se eu dou seguimento, tu só pensa e te reporta a mim. Tudo que sair sai de mim, não é tu, tu só faz pra mim”. E eu fiz isso, e muita coisa saiu, e muita coisa nunca saiu.

Depois assumi a coordenação dos programas de comunicação e marketing, que era o que, no texto que escrevi para o número zero da Barbarói, eu chamava de um escritório de planejamento. Então, a gente juntou assessoria de comunicação e marketing com a ideia de marketing não como publicidade, mas como planejamento e prospecção de mercado. E aí eu fui coordenador disso por seis meses. Foi uma dificuldade muito grande, porque os colegas da Comunicação não entendiam por que era um sociólogo e não um jornalista que coordenava a comunicação. E os colegas da Administração não entendiam por que era um sociólogo e não um administrador que coordenava o marketing. Então, nós transformamos esta coordenação em coordenação de planejamento, e contratamos uma professora da Administração, a Rita Carnevale. A professora Rita Carnevale tinha o apelido interno de "twister", as pessoas diziam que ela era um furacão, que por onde ela passava nada ficava no lugar. E esta professora se reportava diretamente ao Wilson e eu era um assessor informal. Minhas 10 horas para pensar foram canceladas, ela foi contratada, e eu virei assessor informal dela.

Essa coordenação de planejamento tinha muito o enfoque da Administração de Empresas, ela propunha umas coisas muito malucas. Era um tempo da "reengenharia". Então, a questão era "reengenhar" tudo. E ela tinha ligações com o PSDB, que estava no governo do estado com o Antônio Brito. Então, era bem aquela coisa de reengenharia, agências de desenvolvimento, Pólo RS entrando aqui direto. Só que ela se indispôs com todo mundo na instituição pelas patroladas que dava. E aí, quando o Campis foi eleito para ser reitor em 98, ele disse "eu vou criar a PROPLAN, e não vai ser a Rita, vai ser tu, porque a Rita vai ser o espantalho para te aceitar". E onde ele foi falar que queria criar a PROPLAN, perguntavam pra ele: "mas tu vais colocar aquela mulher?" E ele respondia: "sim, tu tens outro nome melhor?". E quando todo mundo estava assustado, ele achou um "nome melhor", que era eu. E aí foi mais ou menos tranquilo a aceitação, ela virou coordenadora de planejamento, e eu pró-reitor. Então, ela é que fazia o operacional e eu era o cargo político. Logo depois ela foi embora, e eu assumi também a parte executiva.

Barbarói, Santa Cruz do Sul, n.59 - número especial, p.<113-154>, Ago./Set. 2021 


\section{Entrevistadores:}

Você acaba de dizer que o seu nome apareceu como Pró-Reitor como resultado de uma estratégia de um projeto de grupo, mas para convencer a comunidade acadêmica que determinado nome não era viável. Mas, naquele momento, você já tinha acúmulo na discussão sobre Universidade, planejamento universitário, experiências que legitimavam seu nome como futuro Pró-Reitor!?

\section{Marcos Moura Baptista dos Santos:}

Sim. Em 1994 eu entrei num Mestrado com um projeto de dissertação em Gestão Universitária. Foi meu projeto de dissertação, tendo como objetivo analisar estrutura de planejamento e sistemas de informações para planejamento na Universidade. Eu não terminei o texto da dissertação, mas a Universidade tinha pago o curso. Daí, como eu não concluí, tive que devolver o dinheiro. Se eu tivesse concluído, teria sido um investimento na universidade. Então, a universidade, de certa maneira, me preparou pra assumir: “vai lá fazer!”. Esse mestrado, realizado na Estácio de Sá, era um mestrado profissionalizante, ainda antes de existir a figura do mestrado profissionalizante. Era um mestrado para resolver o problema de uma série de universidades federais do Nordeste, cujos dirigentes não tinham mestrado. Universidades federais de vários estados nordestinos. Eu era o único, junto com o reitor da Universidade Bandeirante, que não era de um federal.

As aulas ocorriam uma vez por mês e a gente ficava uma semana no Rio de Janeiro. Uma semana por mês. Viajava para lá, ficava o resto do mês aqui. Então, assim, eu comecei a me preparar para isso. Depois disso, já como pró-reitor, em 1998, a universidade me mandou fazer um curso de especialização, organizado pela OUI, que é Organização Universitária Internacional. Então, eu fui fazer esse curso e como monografia de especialização eu fiz um projeto de planejamento universitário. Meu trabalho de conclusão de curso foi a construção de uma pró-reitoria. Agora, naqueles textos que eu escrevo no número zero da Barbarói, eu chamo isso, eu pego, já tá ali a ideia de escritório de planejamento. Transformo, então, nesse projeto para a especialização da OUI e meu trabalho vai ser premiado como o segundo melhor trabalho da América do Sul. Eu vou a Buenos Aires para receber essa premiação, junto com uma colega da Colômbia, que teve a sua monografia escolhida como o melhor trabalho. A universidade mandou todo ano ir alguém fazer esse curso de especialização. Então, toda a reitoria da UNISC, eu, Elizabeth, Luci, Tomé, Campis, Liane, todos nós fizemos, um depois do outro, às vezes dois ao mesmo tempo, fizemos esse curso. Eu fui fazer um estágio no México sobre avaliação institucional, por conta desse curso. E aí em 2000, eu entro no mestrado de Ciências Sociais da PUCRS, que tinha o nome fantasia Organizações e Sociedade, um mestrado profissional. E vou ser orientado pelo Emil Sobotka num projeto que trabalhava com a teoria do Niklas Luhmann para eu propor uma reformulação da estrutura organizacional da UNISC. Um projeto de estrutura e organização numa universidade de pequeno porte, é esse o trabalho. Então, sim, eu me preparei um monte para trabalhar com planejamento, e fui buscar respaldo acadêmico nessas coisas que foram acontecendo, a

Barbarói, Santa Cruz do Sul, n.59 - número especial, p.<113-154>, Ago./Set. 2021 
universidade me mandou para uma, eu busquei outra, eu larguei aquela e peguei outra, para me preparar. E depois eu saio da pró-reitoria por uma questão particular minha, no momento que eu não posso continuar ali, e também porque eu entendia, nesse momento, eu entendia assim "o que precisa agora é outra coisa, o que precisa agora é um trabalho de caráter político que eu não sei fazer, eu sou um técnico de planejamento”. E aí eu falei para o reitor, eu disse "olha, eu não sei fazer isso, eu não sei trabalhar com a Câmara de Deputados, tem que ser outra pessoa". Então, eu saio, fica uns dois ou três meses sem pró-reitor, com reitor acumulando, até que ele vai colocar o professor João Pedro, que vai fazer exatamente esse trabalho de articulação parlamentar, que ele fez muito bem e cujos resultados estão visíveis no marco legal das instituições comunitárias que o João Pedro capitaneou e conseguiu fazer aprovar no Congresso Nacional.

\section{Entrevistadores:}

Isso ocorreu na transição da primeira para a segunda gestão do Campis?

\section{Marcos Moura Baptista dos Santos:}

Isso. Eu saí em dezembro de 2001. Então, 1998, 1999, 2000, 2001. Quando o Campis assumiu de novo, em março de 2002, fiquei mais um ou dois meses. João Pedro vai entrar, então, no segundo mandato do Campis. É daí que vai resultar o curso de Medicina, por articulação política, a gente tinha preparado toda a parte técnica, eu tinha ido buscar os consultores técnicos, que era na UFF, na Federal Fluminense, os médicos dos conselhos. Então, tudo isso. Mas era tudo técnico. E aí a autorização dependia de articulação política. E aí o João Pedro fez esse trabalho, sempre em conjunto com o Campis. Então eu saio porque eu não teria a menor condição de fazer o que era preciso fazer. E tinha uma questão para mim que, na época, era muito importante: eu queria ter um doutorado, eu precisava passar num doutorado. $\mathrm{O}$ Wilson era na época Pró-Reitor de Pesquisa, e o Campis deu um ultimato: "eu não quero pró-reitor fazendo doutorado, só o Wilson, que já está fazendo e tem que terminar esse ano". E aí, vou dizer "puxa vida, o cara disse isso...", eu disse "oh, meu, eu quero entrar no doutorado", "quando é que tu vai fazer?", “cara, eu quero entrar no ano que vem", "não, eu não quero, tu não pode esperar até o fim do mandato?", eu disse "cara, eu vou fazer a seleção, se eu fizer a seleção é porque eu quero passar, eu quero ir”. E aí eu entrei em 2004 no doutorado, mas eu já saí antes, eu saí em 2002, dezembro de 2001, na verdade, estava fora. Então, teve aí uma questão minha, uma questão totalmente minha para sair. E que eu acho que a melhor coisa para universidade, porque eu ficaria tentando fazer uma coisa que eu não saberia fazer. Então, eu acho que foi bom.

\section{Entrevistadores:}

Mas, ao mesmo tempo você, enquanto Pró-Reitor, esteve à frente de um processo importante, num periodo em que a UNISC começou a discutir os PDIs. Que tinha seu caráter técnico, mas, ao mesmo tempo, necessitou sempre de uma articulação política, principalmente na comunidade acadêmica.

Barbarói, Santa Cruz do Sul, n.59 - número especial, p.<113-154>, Ago./Set. 2021 


\section{Marcos Moura Baptista dos Santos:}

Teve um formato político. É verdade. É bem importante dizer que a discussão do PDI foi amplamente participativa. Funcionava com reuniões, com consultas, com decisões dos presentes nas reuniões, não importa se tinha 20,30, 40 ou dois. Todo mundo foi convocado, mas tinha 20, as decisões eram tomadas, então isso era bancado. Então, acho que o processo de construção dos PDIs conforme a gente fez ali, eu acho que funcionou muito, inclusive quando alguns problemas técnicos que depois não funcionava, coisa que não tinha o que fazer, mas era uma decisão política que a gente queria fazer. Então, eu acho que depois houve um aperfeiçoamento técnico e se perdeu a participação. Os últimos PDIs foram muito menos participativos. Então, no meu período de pró-reitor, eu trabalhei o tempo inteiro com essa ideia da participação de todos nas decisões de planejamento e desenvolvimento institucional.

E tinha também, foi criado ali, o PG (Plano Geral), que era o plano do ano, que também era participativo. A gente usava várias técnicas e a professora Rita Carnevale foi muito importante para montar isso. Nós tínhamos um acompanhamento, um monitoramento, que era feito mês a mês. Mas, de novo, mesmo nos PDIs, desenvolvimento institucional, quando chegava na parte de política pedagógica, a gente dizia que pretendia ter o curso este, o curso aquele, o programa esse, o programa aquele, mas nós nunca conseguimos fazer uma discussão mais aprofundada, do que é educação superior, do que deveria ser a política educacional da universidade. Eu nunca consegui fazer avançar nesse negócio, tinha muita resistência dos departamentos.

Misturando um pouco a linha de tempo, nós tivemos, pelo menos três grandes momentos de discussão da estrutura organizacional, no período entre 1993 e atualmente. A ideia de 1993 era acabar, colocar só departamentos, esta era uma ideia que veio da comissão do CNE, era a concepção teórica deles, que entendiam que tinha que eliminar instâncias intermediárias. Poderia ser só faculdade sem departamento, mas aí a comissão disse "vai ser um grande problema político para vocês, vocês vão criar um baronato, 4 diretores de faculdade, com voto, porque todos serão votados, que vão brigar entre eles; é melhor diluir isto em 11 pequenos chefes de departamento, que não vão conseguir se juntar para pressionar a reitoria”. Foi bem isso, cálculo maquiavélico assim. 4 se juntam, é fácil fazer 3 juntar e ganhar. Então, foi feito isso. Depois disso, a gente fez uma discussão em 1996, porque ninguém na instituição queria departamento, na verdade. A discussão foi feita, mas a Reitoria entendeu que não fazia sentido mudar a estrutura àquekla altura, afinal a gente tinha só 3 anos da estrutura departamental, ela não tinha sido testada ainda, não era a hora de alterar. Depois a gente foi fazer uma nova discussão disso lá em 1999 e aí também a ideia era de acabar com os departamentos, e aí a reitoria estava disposta a extinguir os departamentos, mas depois de toda a discussão as pessoas entenderam que não tinha que mexer em nada.

\section{Entrevistadores:}

Já em 1999, então, havia a discussão sobre terminar com os Departamentos e ficar somente com coordenações de curso. É isso?

\section{Marcos Moura Baptista dos Santos:}

Barbarói, Santa Cruz do Sul, n.59 - número especial, p.<113-154>, Ago./Set. 2021 
Só com coordenações de curso, era essa a ideia. Teve algumas dificuldades para resolver a lotação de professores e tal, mas todo mundo achava que o departamento era a instância que não precisava existir. Então, a ideia era ter uma administração superior e os cursos, onde estão os professores, por onde os estudantes se vinculam com a Instituição. É o que precisa. Chefe de departamento serve para que? Para distribuir disciplina, isso não precisa. Mas aí, penso eu, vários departamentos perceberam que perderiam poder e alguns cursos devem ter percebido que eles desapareceriam na nova estrutura.

\section{Entrevistadores:}

Certamente seria um desafio porque, já naquelas alturas, a Universidade tinha uma estrutura complexa, com pesquisa, extensão e pós-graduação. Onde a gestão dessas atividades ficaria sem os departamentos?

\section{Marcos Moura Baptista dos Santos:}

Pois é, tinha isso. Vejam, mestrado de desenvolvimento regional, por exemplo, ele não fica em nenhum departamento. Por quê? Porque ele compreende professores de vários departamentos, de várias áreas, ele era interdisciplinar, mas ele não ficou lotado em nenhum departamento. Mas, de certa maneira, se concluiu que um departamento administra melhor. Na gestão do Wilson foram feitas algumas atividades para montar linhas de pesquisa, porque tinha linha de pesquisa individual, tinha linha de pesquisa do professor. Então, se tenta diminuir linhas de pesquisa, unificar linhas de pesquisa com vários departamentos e essa alteração também não funcionou. Quer dizer, uma linha de pesquisa coordenada por 3 ou 4 departamentos, e isso não funcionou, essa linha não aconteceu. Agora com a reinvenção, eu tive essa conversa com a reitora Carmem Lúcia, de repente vocês já pegaram isso, eu perguntei “professora, não era a hora do centros?" E ela me disse: “é muita novidade pra uma coisa só, vamos reduzir os departamentos sem chamar de centro, departamento a gente tá acostumado a trabalhar assim". Na prática, um departamento que congrega gente de tantas áreas do conhecimento, com tantos cursos diferentes, é um centro, mas vamos chamar de departamento porque estamos acostumados, foi isso que ela me disse. "Mais adiante, se quiser pensar, pensa, mas eu não quero mudar o nome".

\section{Entrevistadores:}

Você foi Pró-Reitor e, nesse sentido, você é um dos colegas do agora ex-Departamento de Ciências Humanas que atuou na gestão da Universidade. Gostaríamos de ouvir sua avaliação sobre essa participação. A importância desse espaço politico para o departamento, mas, também, os desafios pessoais que assumir essa posição compreende.

\section{Marcos Moura Baptista dos Santos:}

A gente sempre teve alguém na gestão superior, com exceção dessa gestão. No início, Campis, vice-diretor, superintendente de extensão, pró-reitor de extensão, pró-reitor de pesquisa, reitor. Eu, pró-reitor. João Pedro, pró-reitor. A Paula foi coordenadora de extensão

Barbarói, Santa Cruz do Sul, n.59 - número especial, p.<113-154>, Ago./Set. 2021 
quando esse cargo tinha uma importância política bem maior. Acho que, politicamente, para o departamento sempre foi importante. E eu penso que, ao mesmo tempo, para a Universidade também sempre foi importante ter um de nós lá, porque em inúmeros momentos foi dito isso, tanto para o Campis quanto para mim: "não, vocês entendem mais de universidade, vocês têm uma compreensão de como funcionam as instituições". Então, em alguns momentos a reitoria usava isso aí e nos colocava para falar, "vai lá, tu não tens título, mas tu vais saber falar". Então, era isso. O Wilson tinha essa clareza muito grande; que, para certas questões, era melhor ter um sociólogo falando. Então, eu penso que, para o departamento sempre foi muito importante. Uma coisa muito pragmática, inclusive para ter aula para todo mundo, inclusive para assegurar alguns avanços e também para brecar certas mudanças, que só não foram adiante porque tinha uma barreira na gestão superior. Por que se não, então algumas decisões poderiam ter sido tomadas, como a eliminação de disciplinas das ciências humanas.

\section{Entrevistadores:}

Mas essa questão que você coloca é interessante. Por que no Colegiado do Departamento de Ciências Humanas não foram poucas as vezes que, no período em que vocês estavam na Reitoria, se cobrou mais em defesa dos interesses das Ciências Humanas na Universidade. Ou seja, havia a leitura de que vocês poderiam ter uma posição diferente, que poderiam ter encampado visões que estavam presentes no Departamento quanto à Universidade, quanto à participação das Humanidades na formação universitária. Faz sentido essa "reclamação" do Departamento?

\section{Marcos Moura Baptista dos Santos:}

Faz sentido. Eu tenho clareza disso. A gente tinha um trabalho de evitar certas coisas, mas nós nunca conseguimos avançar. Era um trabalho defensivo mesmo. Nunca conseguimos avançar, e eu penso que deveríamos ter tentado em alguns momentos. Aí tinha muito o jogo de forças dentro da reitoria envolvendo a PROGRAD. Claro que a escolha do pró-reitor, da pró-reitora sempre foi do reitor, mas nós nunca conseguimos ter um pró-reitor, uma pró-reitora - fosse a Elizabeth, a Luci, a Carmem Lúcia - que bancasse uma política de ensino baseada nos valores e princípios da universidade. Eu, na condição de colega da pró-reitora, cobrei mais de uma vez, o reitor sempre manteve a distância, mas eu cobrei mais de uma vez. E aí me foi dito, por ela, "vem junto, vem junto para ver como é conversar com coordenador de curso". E eu disse: "mas eu não quero conversar, quero aprovar no Conselho Universitário uma política, e fazer cumprir". E ela disse: "mas não é assim que funciona". E aí, na minha leitura particular, nos casos específicos da Carmem Lúcia e da Elizabeth, elas se submeteram aos interesses dos cursos. A Luci, me parece, não tinha pretensões políticas, e não estava muito preocupada em fazer articulação. Ela não conseguiu fazer, mas ela não estava se submetendo aos cursos. Agora, a Elizabeth, mais de uma vez, ela voltou e me disse "não vou bater". E a Carmem, bem, eu nunca tive intimidade com ela para discutir isso, mas, mais do que uma vez, eu percebi que ela não estava disposta a brigar. Eu lembro que teve uma discussão pública, em 2008, em torno de um documento que eu discordava de muitos pontos e eu reclamei muito. Ela me chamou em particular e me disse "você viu os nomes que tem aqui no documento?".

Barbarói, Santa Cruz do Sul, n.59 - número especial, p.<113-154>, Ago./Set. 2021 
Eu perguntei: “quem?" E ela abriu para mim na equipe e me disse: "olha". E lá estavam nomes como, por exemplo, do Flávio, do César, colegas do Departamento, que foram relatores, onde tudo que estava escrito sobre as humanidades foram eles que escreveram. E ela me disse: "foram eles os relatores, você acha que a gente não está tentando fazer, mas você não sabe o que é fazer isso aqui, você está falando sem saber". Foi a única vez que ela falou comigo dizendo "olha, você devia agradecer por ter sido feito isso aqui, e agradecer porque o Flávio e o César estão aqui nessa equipe”. O que ela queria dizer é que sem a presença deles seria bem pior.

\section{Entrevistadores:}

Mas a atual proposta de "Reinvenção"? Em sua avaliação, essa proposta consegue ir adiante somente em função da crise que a Universidade está enfrentando nos últimos anos ou ela expressa mudanças nas visões acerca das concepções de Universidade Comunitária? Esse projeto teria aceitação, por exemplo, se fosse discutido em 2012, quando a Universidade vivenciava um periodo de crescimento/expansão?

\section{Marcos Moura Baptista dos Santos:}

Eu acredito que não seria. Se tivesse aluno, tivesse aluno agora, esse projeto não seria discutido; e se fosse não seria aprovado desse jeito. Mas agora, com escassez de alunos, os cursos querem reduzir preço, reduzir carga horária, reduzir exigências. Mas, mesmo antes disso, em mais de um momento os cursos claramente disseram, na discussão da formação em geral e da formação por área que tinha que eliminar as humanidades, ou ao menos reduzir fortemente a sua carga horária. Eu me lembro, eu tive essa conversa em vários lugares. Por exemplo: Sociologia Aplicada à Saúde é formação específica na área da saúde, não é formação geral. Formação geral é Sociologia. Porém, Sociologia Aplicada à Saúde aparece como formação geral. Você considera os documentos do MEC, não deveria ser, mas é, porque o curso tem mais força. Agora deu para fazer isso aí, porque os cursos, os professores estão acuados. Teve uma série de tensões. Então, eu penso que, noutra conjuntura, seria diferente. Agora, a pergunta se isso foi feito somente pela conjuntura, eu penso que sim. Porque a Carmem assumiu em 2014 e até em 2016 as falas eram: "ah, é problema do governo, acabou o FIES” e essas coisas. Mas não tivemos nenhum outro movimento para mudar nada, nenhum plano B. Somente depois do primeiro PDV (Programa de Demissão Voluntária), penso eu, que começaram a pensar em algo maior.

\section{Entrevistadores:}

Nesse sentido, em sua avaliação seria mais interessante fazer essas mudanças anteriormente? Por exemplo, desde 2008, ou talvez antes, havia a compreensão de que o modelo de Universidade deveria ser pensado. E poderíamos ter realizado isso com a possibilidade de um enxugamento mais racional, inclusive porque éramos menores. E talvez a gente esteja pagando um preço alto, por não ter visualizado essa necessidade em momentos nos quais a Universidade não estava vivenciado crise financeira.

Barbarói, Santa Cruz do Sul, n.59 - número especial, p.<113-154>, Ago./Set. 2021 


\section{Marcos Moura Baptista dos Santos:}

Exato. Eu penso isso. Para mim, é certo que a gente estaria muito melhor se tivesse feito. Eu penso que agora é assim. E esse projeto que está aí é um projeto que surge da necessidade de fazer alguma coisa, então se pega o que todo mundo está fazendo. E também tem uma conjuntura política no próprio COMUNG, que é isso que está acontecendo com todos nós, o que nós estamos fazendo, então todo mundo faz uma coisa muito parecida. $\mathrm{E}$ aí tem os vendedores de projetos, os vendedores de cursos, não é só a UNISC que comprou esse projeto, esse pacote, tem outras que estão fazendo igual dentro do COMUNG. E aí tem uma concepção de universidade que foge do que a UNISC sempre disse que era e o que queria ser. Então, eu acho que tem uma concepção que reduz a perspectiva democrática. Eu acho que reduz, reduz muito. Veja, o conselho universitário tem seis chefes de departamento, tem os outros membros vinculados à Universidade, tem a reitora e dois pró-reitores, que votam, os outros não votam. E aí, como é que fica. Os diretores não votam, os diretores de pró-reitoria não votam. Votam só os pró-reitores. Mas aí entram os coordenadores de curso, que agora farão parte do CONSUN, 8 coordenadores de curso, que serão escolhidos pelo conselho de graduação. Mas isso era para ter um número lá que seja maior do que a soma de estudantes e da comunidade, não é para aumentar a participação. A proposta é reduzir os representantes da ADUNISC de 3 para 2, da AFUNISC de 3 para 2, reduzir, reduzir, reduzir... A ideia da "reinvenção" é ter um conselho enxuto, que tem menos debate, gasta menos tempo e funciona melhor. Será? Então, tem uma concepção que está aí. Essa concepção, para mim, traduz um pouco como se olha a universidade hoje, sob a hegemonia da área de negócios. Retrospectivamente, se a gente olhar aquele documento da UNESCO lá de 1998 (Tendências da Educação Superior para o Século XXI), lá dizia, tem dois modelos, um modelo UNESCO, e um modelo OCDE. Eles não dizem com esse nome assim, mas eles mostram quais eram os modelos, e o nosso modelo era UNESCO. E, bom, hoje não é mais um modelo mundial. Então, eu acho que sim, se tivesse feito alguma coisa lá em 2008, sem dúvidas nós estaríamos na frente, nós seríamos provavelmente referência. Se tivesse feito alguma coisa quando começou a cair ali em 2014, se tivesse feito alguma coisa antes de 2016, a gente estaria começando a recuperar agora, e não simplesmente tentando. Só que não tinha um modelo, eu penso. O que tinha para fazer ali? Não se sabe como é que nós faríamos. Mas já era hora de estar fazendo, faltou planejamento, faltou PROPLAN. E agora se tornou meio inevitável fazer. E aí foi isso, o COMUNG busca uma solução e a UNISC incorpora a solução. A palestra com o reitor da UNIJUÍ deixa claro, é a mesma coisa, eles chegam ao fundo do poço e ficam inadimplentes, ficam deficitários e se reorganizam. Nós, de certa maneira, fazemos o mesmo. Só que tem certas coisas que lá, por exemplo, nas diretrizes orçamentárias da UNIJUÍ aparece como diretriz que o gasto com pessoal pode ser de $50 \%$ no máximo da receita líquida. E no nosso isso não está escrito. A ideia da pró-reitoria de administração é que a gente não bata nos $70 \%$ e tente diminuir ainda mais. Mas não está escrito um teto, nas nossas diretrizes orçamentárias não está escrito isso. Mas a Reitoria se move por essa ideia. E essa diretriz implica numa série de coisas. Por exemplo, para se conseguir reduzir a folha de pessoal abaixo dos $70 \%$ da receita líquida é preciso demitir pessoas. Simples assim, sem nenhuma outra consideração.

Barbarói, Santa Cruz do Sul, n.59 - número especial, p.<113-154>, Ago./Set. 2021 


\section{Entrevistadores:}

Pensando a sua condição de sociólogo. Como você avalia sua condição de Sociólogo, considerando sua trajetória enquanto professor, mas também como gestor de uma Universidade?

\section{Marcos Moura Baptista dos Santos:}

Pois é. Eu lembro que em algum momento, quando ocupava a Pró-Reitoria, eu disse que me sentia mais administrador do que cientista social. E foi isso. Eu mergulhei numa área em função das necessidades colocadas. Eu não deixei de estudar e de pesquisar questões relacionadas à Sociologia, mas eu me desatualizei nas minhas leituras. Eu demorei muito para ler certos autores importantes da área, porque eu estava lá lendo marketing, estava lendo SIG Sistemas de Informações Gerenciais. Então, eu estava estudando administração e planejamento muito mais do que sociologia. Eu cheguei a assinar a Revista de Administração da Fundação Getúlio Vargas, dentre outras da área da administração. E parei de ler as revistas de sociologia. Teve um custo pessoal para mim que, inclusive, com certeza, chegou nas minhas aulas. Eu estava lá dando aula com manual, porque eu já não tinha mais certas leituras atualizadas. Então, eu vejo claramente, que eu passei a participar de congressos e reuniões de gestão universitária, de administração, de planejamento. E não ia em eventos das ciências sociais. Eu não ia mais em reuniões da ABA, a Associação Brasileira de Antropologia, que era um lugar que eu sempre ia. Deixei de ir para a ANPOCS, porque tinha que escolher. Então, teve um custo sim, eu quase deixei de ser sociólogo. A retomada da Sociologia vai se dar por conta do doutorado na UFRGS, que eu não terminei, mas os créditos me colocaram de novo em dia com as discussões atuais da área. De repente estava eu novamente lendo Boaventura, aprofundando Habermas, retomando Bourdieu. E depois disso, eu pude até dar aula de Habermas no curso de Ciências de Sociais. Então, sim, teve um custo alto. Por outro lado, eu acho que teve um reconhecimento ser Pró-Reitor, “o Caco foi Pró-Reitor!” Não só institucionalmente, mas na própria cidade, as pessoas perguntam, né, "ah, tu não era vice lá? Tu não vai voltar para a pró-reitoria?”. Então eu acho que sim, teve um reconhecimento da coisa, o cara foi pró-reitor da UNISC, apesar de ser sociólogo, não deve ser tão pouca coisa. Com certeza, eu faria tudo de novo, mas sem deixar de me manter a par dos lançamentos da Sociologia. Porque eu tinha um medo muito grande de não dar conta da parte de gestão, e eu me arrebentei estudando gestão, e hoje eu percebo que daria para dar conta disso, até porque o nível médio de leitura de aprofundamento do pessoal da gestão é muito pequeno. Então, sabe, leituras de Sociologia me seriam suficientes para compreender como funcionam essas coisas. Mas, na época, eu não sabia disso. Eu não sabia disso, eu tinha medo de falhar. Eu fui aprendendo. Por outro lado, eu aprendi horrores sobre a universidade, muita coisa mesmo, sobre a universidade em geral, sobre a UNISC, sobre planejamento, sobre orçamento. Para mim isso foi um ganho, hoje, sem falsa modéstia e sem cabotinice, eu tenho um vasto conhecimento sobre isso tudo.

E tem uma coisa também, eu nunca fui um pesquisador, eu nunca tive interesse em ser um pesquisador, eu pensava em ser um extensionista. Aí, quando eu começo a assumir cargos e funções administrativas, eu digo para mim mesmo, "então tá, o meu caminho é a gestão, eu vou ser um burocrata da universidade, ok". Então, eu fiz isso. Desde 1988 eu perdi a conta de

Barbarói, Santa Cruz do Sul, n.59 - número especial, p.<113-154>, Ago./Set. 2021 
quantos mandatos de chefe de departamento eu tive. Nesse período todo eu fui vice-coordenador de curso, do curso de Ciências Sociais, mas eu nunca fui coordenador de curso, porque não era uma coisa que eu tinha condições de fazer, então eu fui vice, botei meu nome lá; mas departamento eu não teria nenhum problema de ser o chefe de departamento de Ciências da Saúde hoje, que administraria tranquilamente. Então, tenho um bom domínio disso. É isso, mas deixei de lado muita coisa. Na verdade, não foi um custo pessoal, familiar, mas teve um custo intelectual, né. Não trabalhei mais do que eu trabalharia se eu não tivesse assumido, não deixei de ter tempo para a família, não deixei de fotografar.

\section{Entrevistadores:}

Quais são suas principais motivações de luta atualmente, enquanto intelectual, mas, também, enquanto alguém que, pela experiência de atuação na Universidade, tem compromissos com o pensar a formação universitária e o próprio desenvolvimento da Universidade, em especial a Universidade Comunitária?

\section{Marcos Moura Baptista dos Santos:}

Hoje, o que que motiva? Mais e mais é pensar em metodologia de ensino e aprendizagem. $\mathrm{O}$ que eu percebo, é a grande falha da universidade, tem muito rodízio, quem tá pensando isso trabalha com a ideia de start ups e coisas do tipo, buscar páginas de $\mathrm{N}$ instituições inovadoras e "disruptivas", e não discute o concreto: tá, como é que o aluno na sala de aula consegue, por conta disso, aprender alguma coisa e como é que se consegue formar um sujeito que faça diferença para a sociedade? Então, hoje eu tenho estudado isso, um pouco em função da situação atual da universidade, da reinvenção, mas também porque me desafia. Eu fico pensando "tá, eu sempre tive muito orgulho das minhas belas aulas, eu acho que eu sou um professor que encanta os alunos, mas será que esse encantamento se concretiza numa aprendizagem, ou simplesmente o aluno fica admirando o professor e não aproveita aquilo nada?" E esta é uma dúvida que eu tenho, muito, porque muitas e muitas vezes os alunos me pegam: "professor, tu foi o melhor professor", "olha, isso sim, tu tinha que ter aula com esse homem, as aulas de Filosofia dele", e eu respondo "Sociologia", "ah, é!", sabe? "As melhores aulas de Filosofia que eu já tive", "pois é, eu dou aula de Sociologia...”. Então, o cara lembra de mim como um bom professor, mas ele acha que era Filosofia. Então, eu fico pensando até que ponto não ficou só um encantamento com um professor, com as histórias. Hoje, lembro do estudo que contar histórias é muito importante para ensinar. Storytelling é uma das modas disruptivas aí, né, mas eu sempre fiz isso. Sempre gostei de dizer para os alunos que não dava aulas, que contava histórias. Então, eu percebo que é importante, mas que tem que ver concretamente o que é que fica pro aluno.

Então, hoje eu tenho estudado isso. E para a universidade é muito importante ter gente que entenda de metodologias ativas e de novas tecnologias e, ao mesmo tempo, seja crítico dos modismos e enxergue as picaretagens. E eu acho que falta gente assim na educação. E se a gente olhar por aí, o que a gente vê é que quem mais faz isso hoje são os sociólogos mesmo. Quem tem melhor produção aí são os sociólogos, os cientistas sociais. Não são os pedagogos, são os cientistas sociais. Então, esse é um caminho que pretendo continuar trilhando, no

Barbarói, Santa Cruz do Sul, n.59 - número especial, p.<113-154>, Ago./Set. 2021 
tempo que eu vou ficar aí, sei lá quantos anos mais. Eu estou com 60 anos, até os 65-70 eu vou ficar, depois não sei.

Mas deixa eu falar uma coisa, para não esquecer, bem específica, sobre a reorganização departamental, da "reinvenção" da UNISC. Nosso departamento de Ciências, Humanidades e Educação. Eu não gosto do nome, acho que não é adequado. Eu preferiria que fosse "Departamento de Ciências Básicas e Formação Geral". E aí teria que se discutir o que é formação geral. É aí que eu botaria o lugar das humanidades na universidade, na formação geral. A base da formação geral na universidade são as humanidades. É isso que eu penso. E as ciências básicas, que aí, bom, né, Física, Química, a própria Pedagogia, e tal, mas a ideia da formação geral, que não é a formação geral como a "reinvenção" está chamando aqui na instituição, não os módulos de formação geral, mas a ideia de formação geral mesmo, por aí que eu pensaria na revitalização e qualificação da formação de graduação com base nas humanidades (ciências humanas e sociais, letras, artes, filosofia, linguagens).

\section{Entrevistadores:}

Talvez nesse momento possamos retomar, mas sugerir também uma avaliação mais ampla do seu momento enquanto Pró-Reitor. Certamente é um marco importante na trajetória de qualquer um de nós acadêmicos fazer parte da alta gestão. Em especial quando se assume a posição de Pró-reitor.

\section{Marcos Moura Baptista dos Santos:}

Queria retomar um pouco a reflexão sobre o modelo comunitário da época e a transição de sentido que eu penso que teve nesta definição do comunitário para o que a gente tem hoje. Quando na UNISC se falava comunitária, na última década do século passado, era principalmente a ideia da origem na comunidade. Alguns, inclusive, destacavam que isso era uma característica da região, era uma característica da imigração alemã, sempre surgia o exemplo da AFUBRA e das cooperativas, do histórico das cooperativas aqui do município. Eu lembro que a professora Virgínia, mais de uma vez dava o exemplo da "aula alemã", em que os imigrantes designavam um deles, com melhores aptidões intelectuais, para ser o professor, e aí esse era dispensado de trabalhar na lavoura, os vizinhos davam conta dessa sustentação, porque ele tinha que educar as crianças. Depois vêm as escolas comunitárias, tem um monte de escola comunitária na região. Então tinha muito essa coisa: nós somos comunitários porque isso é uma tradição da imigração alemã. E isso pegava muito bem na elite da cidade, mas não dava inserção na comunidade, de verdade. Então, inicialmente, tinha essa ideia. Depois se incorpora, na construção da universidade, o comunitário, numa discussão que vai acontecer, não só aqui, mas em todo o Rio Grande do Sul, muito a partir da lógica da FIDENE/UNIJUÍ, que era o modelo paradigmático de instituição comunitária, de universidade comunitária. E aí se cria o COMUNG. E a FISC é, naquela época, a única instituição de ensino superior que ainda não era universidade no COMUNG; todas as demais já eram universidades. E a ideia do COMUNG, então, como consórcio comunitário, aparece nos documentos iniciais do COMUNG, muito a partir dessa elaboração. Tinha uma professora, que eu não consigo lembrar o nome agora, que foi pró-reitora da UPF e fez tese de

Barbarói, Santa Cruz do Sul, n.59 - número especial, p.<113-154>, Ago./Set. 2021 
doutorado sobre isso. Ela colocava ali na tese uma coisa que depois foi usada politicamente pelo COMUNG: "existem as verdadeiras comunitárias e existem as que se dizem comunitárias; por exemplo, as confessionais não são comunitárias, porque elas pertencem a uma congregação, então elas não pertencem à comunidade”. E, com isso, o COMUNG se cria, de certa maneira, buscando o fortalecimento das IES comunitárias em relação às confessionais (a PUC e a UNISINOS, aqui no Rio Grande do Sul); na disputa por recursos públicos para a educação superior, em última instância. Bom, bem mais recentemente, século XXI, sei lá, 2012, 2013, o COMUNG incorpora a PUC, incorpora a UNISINOS, e incorpora a ULBRA, então aquele argumento de que existem comunitárias e comunitárias deixa de ser usado dentro do próprio COMUNG, pois agora "somos todos comunitários", sejamos confessionais ou não. E aí é a ideia do público não-estatal que fica forte. Ou seja, temos uma transição no discurso sobre o comunitário.

As confessionais entraram, mas houve forte resistência antes disso. Por exemplo, a UNIJUÍ e a UPF não aceitavam muito. Nós não, nós não colocamos muitos questionamentos. A UNISC, naquele momento, acha muito bom. É a gestão do Thomé como reitor, acho que é a segunda gestão do Thomé como reitor. Quando essa lógica da pureza comunitária já tinha se perdido, antes ainda da gestão do Thomé, já no segundo mandato do Campis na reitoria e com o João Pedro como pró-reitor de planejamento, a UNISC trabalhou fortemente no público não-estatal, conseguindo que fosse aprovado uma lei no Congresso Nacional, definindo o público não-estatal, ainda que com o nome de "marco legal das instituições comunitárias". E como, para poder aprovar lei no congresso, é preciso apoio político, mudou-se o discurso em busca desse apoio, especialmente o apoio da ABRUC (Associação Brasileira de Universidades Comunitárias), que era comandada pela PUC do Rio de Janeiro. A PUC-Rio era comunitária, se dizia comunitária, como todas as PUCS; e com o apoio das PUCS se garantiu a aprovação desta lei. E, então, se a ABRUC considera que as confessionais são comunitárias, por que o COMUNG, que vai buscar esse apoio, não iria considerar? E, então, acabou a separação entre comunitárias e "verdadeiras comunitárias".

\section{Entrevistadores:}

Você levanta uma questão importante. Por que poderia ser pensado que havia uma complementaridade entre essas duas experiências de Universidades. Você coloca que não, que eram compreensões diferentes, que em determinado momento se esperava institucionalizar a ideia de universidade comunitária, nos termos legais. Mas daí, na sua avaliação, a introdução dessa categoria, "público não-estatal”, promove mudanças com compromissos que uma de Universidade Comunitária implicava?

\section{Marcos Moura Baptista dos Santos:}

Eu acho que promove, mas isso é consequência, não é ideia. A ideia é: a gente tem que aprovar alguma coisa que nos tire do limbo legal em que a gente existe. E essa ideia do marco legal das comunitárias ajuda muito. Marco legal das comunitárias, só que o que está escrito na lei é público não-estatal. A PUC do Rio historicamente teve o seu crescimento financiado pelo dinheiro público. Todos os laboratórios da PUC do Rio são públicos, a COPE, que é a

Barbarói, Santa Cruz do Sul, n.59 - número especial, p.<113-154>, Ago./Set. 2021 
parte de Física e Engenharia, a COPE da PUC Rio é toda ela financiada com dinheiro público, e os professores são também professores das federais. Então, quando o COMUNG dizia "a gente também tem esse direito, de ter esse recurso", ouvíamos "não, mas vocês não são uma PUC". Fazer essa legislação que nos equiparasse a todos, obrigou a abrir certas coisas. Na época, a gente brincava nas reuniões do COMUNG, que nós estávamos deixando de ser a aldeia gaulesa que resiste: "não, não somos mais". Além do Rio Grande do Sul, essa reivindicação de uma verdadeira comunitária, tinha uma universidade do interior de São Paulo, em Piracicaba, que era uma comunitária no mesmo modelo do COMUNG, mas era só aí. As próprias comunitárias em Santa Catarina, da ACAFE, eram fundações municipais, eram bem diferentes do nosso modelo. Mas nós tínhamos uma identidade política com eles e não fazia mais sentido, penso eu, por isso mesmo, se apegar nessa coisa de "nós somos mais comunitários do que eles".

\section{Entrevistadores:}

Aproveitando a referência das Comunitárias de Santa Catarina. Elas compreendem Fundações Municipais. São assumidas pelos Municípios. No caso da UNISC essa possibilidade nunca foi discutida? Já foi dito anteriormente que, desde o início, as municipalidades da Região não demonstraram interesse em assumir grandes compromissos com a Universidade. Mas internamente, na comunidade acadêmica, essa possibilidade chegou a ser discutida?

\section{Marcos Moura Baptista dos Santos:}

Não. A gente tinha, na época que eu estava mexendo nisso, seja na criação da UNISC, seja como pró-reitor, uma proximidade muito grande com a ACAFE, com a Associação Catarinense das Fundações Educacionais, que era a entidade que congregava essas fundações educacionais municipais. Exemplo melhor sucedido é a FURB de Blumenau, Fundação Universitária Regional de Blumenau. Bem sucedido por quê? Porque Blumenau é um município rico. Outra, a UNISUL, também é de um município rico, Criciúma. E a gente percebia que as outras não deslanchavam porque o município era pobre. Trazendo para cá, para o Rio Grande do Sul, a gente teria Caxias, Santa Cruz do Sul e talvez Passo Fundo, como os três municípios em condições de bancar sua universidade. Não tinha a menor chance de Cruz Alta, Ijuí, Bagé fazerem isso. E a gente sabia que politicamente o município de Pelotas não entraria nessa de apoiar a UCPel, considerando que tinha uma universidade federal no município.

Então, teve essa discussão e se entendeu que não fazia sentido, não era viável para nós do Rio Grande do Sul, a lógica da ACAFE. E tinha um movimento de muitos municípios em Santa Catarina que procuravam se desvencilhar dessas fundações justamente pelo peso financeiro no orçamento municipal.

Eu penso que o comunitário, como um modelo do COMUNG, do "verdadeiro comunitário", foi abandonado pela realpolitik, que era a necessidade de fazer essas alianças mesmo ao preço de se permitir certas liberalidades com o conceito. Eu lembro que quando eu estava começando a escrever a tese de doutorado - que eu nunca terminei - na qualificação eu

Barbarói, Santa Cruz do Sul, n.59 - número especial, p.<113-154>, Ago./Set. 2021 
levantava a seguinte pergunta de pesquisa: “comunitário é realidade ou é grife?" E havia duas hipóteses para responder, que aparecia nas entrevistas: "é grife, é o que nos permite nos distinguirmos, então a gente, na verdade, não tem uma interação muito grande com as comunidades, não vem das comunidades, mas ser comunitário é uma coisa que atrai estudantes, que atrai parcerias, então a gente está hoje mantendo a grife comunitária, embora na essência já não seja mais comunitária". E a outra hipótese que aparecia era: "não, não é grife, a gente não consegue mais ser comunitário como era, porque crescemos, porque as instituições cresceram, mas é importante continuar sendo comunitário para buscar financiamento, porque se a gente não for comunitário, a gente é particular, e nós somos contra dar dinheiro público para educação particular, se a gente é contra isso no ensino médio, no fundamental, por que seria a favor na universidade? Então, somos comunitários para nos distinguir das privadas ou particulares".

Estou falando de particulares como privadas, diferentes das comunitárias. Na LDB de 1996, tem um artigo que coloca quatro modelos: o estatal, o confessional, o particular sem fins lucrativos e o privado com fins lucrativos. Então, esse particular sem fins lucrativos é o que a gente queria que fosse chamado de comunitário, ainda nos distinguindo das confessionais na época. Depois as confessionais entram e o discurso é que elas são confessionais, mas isso não é a principal característica delas, a característica principal é que elas são sem fins lucrativos. As PUCS não têm fins lucrativos, embora elas sejam propriedade de uma congregação religiosa e se reportem a uma igreja (católica, luterana, metodista). Então, o "sem fins lucrativos" era o que nos unificava a todos, e era o caminho mais viável para poder receber recursos, e é por aí que o COMUNG vai trabalhar, que o João Pedro vai trabalhar. E por que continua sendo chamado de marco legal das comunitárias? Porque aí também estão também os hospitais comunitários. Os hospitais comunitários, que não são somente de universidades, têm vários hospitais comunitários de associações comunitárias e filantrópicas não universitárias, e eles estão nessa mesma categoria do público não estatal e recebem recursos também.

Agora, tem algumas diferenças, como sabemos. Um dos motivos que sempre nos levou a uma distinção em relação às confessionais é que nós temos dinâmicas democráticas. A gestão democrática e as decisões colegiadas seriam as características das "verdadeiras comunitárias" e isto nos distinguia de todas as outras. Tem documentos do COMUNG, tem documentos da UNISC, que escrevem isso, nos caracterizando como comunitária por causa, dentre outras coisas, da gestão democrática, das decisões colegiadas e participativas. Então, se trabalhava com essa distinção. Ora, a PUC São Paulo era assim, o processo de democratização da PUC-SP foi um marco nas lutas pela democratização do país nos anos finais da ditadura de 64. Mas a PUC-RS, a PUC-RJ, não tinham essa característica. Então, a gente dizia: "a PUC São Paulo é modelo democrático, mas as outras não", nós temos debates e documentos onde isso aparece.

Inclusive para reitor, a PUC São Paulo teve eleições diretas. Já na década de 1980, a primeira reitora de PUC em todo o mundo foi eleita em eleição direta com participação de estudantes e professores na PUC-SP. Então, se a PUC São Paulo consegue funcionar assim, por que nós não? Veja, no primeiro PDI da UNISC estava escrito assim: "O empenho pelo

Barbarói, Santa Cruz do Sul, n.59 - número especial, p.<113-154>, Ago./Set. 2021 
aprofundamento da democracia deve perpassar todo o funcionamento da UNISC, baseado em decisões emanadas de órgãos colegiados. A prática democrática interna deve constituir-se um compromisso inalienável, com a crescente democratização da sociedade, tornando a democracia parte integrante da função universitária, ao lado da pesquisa, da extensão e do ensino". É claro que isso é papel, mas a ideia que a gente tinha era essa, as funções da universidade são: ensino, pesquisa, extensão e democracia. Ou ensino, pesquisa, extensão e democratização. O documento vai ter uma série de coisas dizendo que o papel da universidade era democratizar a sociedade. E, novamente, a UNIJUÍ é a referência para isso, com a ideia de que tem eleição direta para todos os cargos em todas as instâncias. Só que mesmo dentro do COMUNG, na UCS, isso nunca foi verdade. O colegiado maior da UCS, o colegiado de Administração da UCS era composto por sete pessoas, duas indicadas pela prefeitura, duas indicadas pelo estado, e as outras três eram professores da PUC (reitor, vice-reitor e mais um professor indicado). O modelo da UCS sempre foi autocrático e ela foi a universidade que mais conseguiu crescer, e esta era uma tensão: será que não é porque eles tomam decisões assim, decisões mais ágeis, sem perder tempo com o debate democrático? Eu sempre argumentei que não. Eu dizia: "bota a UNISC em Caxias e a gente cresce; olha a cidade, olha o tamanho da cidade, olha a economia da cidade". Eu sempre argumentei isso: . "olha a UNIJUÍ, a crise da UNIJUÍ. Onde é que está a UNIJUÍ? No Noroeste, que está economicamente caído, a região da UNIJUÍ não tem força econômica".

E a UNIJUÍ está numa região em que também existiam outras universidades, em Cruz Alta, em Santo Ângelo, dividindo os recursos e a demanda da região. Então não tinha força para manter tudo isso. E a UCS centralizada e sozinha na região da serra. É bem mais recentemente, já no início do século XXI que a gente vai ter uma infinidade de outras instituições por ali. Mas a UCS sempre foi soberana ali, se expandiu, depois se regionalizou para Vacaria, Flores da Cunha, Bento Gonçalves. E sempre foram decisões autocráticas, seja pelo estilo do reitor que ficou anos e anos como reitor, seja por esse modelo. Eu lembro que, quando surgiu uma oposição na UCS, com o José Clemente Pozenato, que era vice-reitor e se lançou com uma plataforma que era de democratização da universidade, ele foi esmagado. Então, a UCS não era esse modelo. A UNIJUÍ era, a UNISC era.

A UPF também não era, apesar do discurso, porque o reitor lá foi o mesmo por mais de vinte anos. Sabe, então não tinha essa. Era manutenção, era o mesmo reitor, ela repetia, repetia, repetia, por indicação do conselho universitário. O que vai trazer as eleições diretas para a UPF, uma modificação que vai acontecer lá por 1996, 1998, foi que o padre resolve que ele vai se aposentar, que ele não quer mais ser reitor. E a partir daí tem eleições e o grupo que dominava a UPF vai rachar em dois e vai ter disputa sempre entre dois do mesmo grupo. Mas agora são eleições diretas. Então, esse modelo da democracia, baseado em eleições diretas, em decisões colegiadas, em gestão democrática, aparece muito presente no discurso do COMUNG, embora na prática a gente, a UNISC seja uma das poucas instituições efetivamente democrática.

Eu lembro que na época, mais de uma vez, especialmente no mandato do Wilson, quando a gente estava se firmando como universidade, que os colegas das outras instituições do COMUNG vinham aqui e diziam: "mas vocês são exagerados, por que ter $20 \%$ de estudante

Barbarói, Santa Cruz do Sul, n.59 - número especial, p.<113-154>, Ago./Set. 2021 
no CONSUN? A lei fala até $20 \%$, não precisa ser os 20 ". E a gente respondia: "A lei diz que pode ser até vinte, mas nós queremos mais, então a gente vai botar o máximo que a lei nos permite". "Ah, mas isso não funciona". Então, se tinha um sentimento democrático, no sentido de que não se aceitariam perseguições políticas, que ninguém sofreria por isso, que você podia se expressar e tal, mas na formulação legal os espaços eram mais restritos.

Esta é a minha leitura da época, o discurso democrático do COMUNG vem da UNISC e da UNIJUÍ. E que eu acho que aqui tem a ver com a discussão do país mesmo. Veja, em 1984 tem a emenda das diretas (Emenda Dante de Oliveira) e em 1986 a UNISC institui eleições gerais para todos os cargos de direção. E depois a gente não vai parar mais, nós vamos ser universidade em 1993, em 1992 ainda teve o fora Collor com os estudantes participando. Então, eu acho que é interessante pensar o período histórico que leva a FISC se tornar a UNISC, a radicalizar a experiência democrática, e quando a gente entra no COMUNG, a gente arrasta muito isso. A gente faz muito, leva muito essas coisas.

\section{Entrevistadores:}

Então, em sua avaliação, a conjuntura política de criação da UNISC favoreceu a proposta de uma gestão democrática!?

\section{Marcos Moura Baptista dos Santos:}

Sim. Eu penso que aquela conjuntura facilitou para nós que, naquelas alturas, estávamos à frente do processo, conseguimos que nosso discurso fosse incorporado também pelos estudantes. Porque, como a gente pensava dessa maneira, a gente teve o apoio do DCE e dos estudantes, e eu acho que isso foi determinante para a decisão de que o nosso grupo político, que nunca se pensava como um grupo, mas que existia na prática, tivesse sido vitorioso nas eleições diretas para a FISC de 1986. Porque a gente disputou contra um grupo que pensava exatamente o contrário disso. $\mathrm{E}$ eu penso que muitos professores, e com toda certeza os estudantes, tinham uma clareza de que o nosso enfrentamento era contra a prefeitura e contra a elite local. Porque, independente de todos os estatutos, a prefeitura botava o dedo aqui dentro e dizia quem seria o candidato a ser homologado pelos conselhos na direção geral e na direção das faculdades.

\section{Entrevistadores:}

\section{A Prefeitura tinha essa força?}

\section{Marcos Moura Baptista dos Santos:}

Tinha essa força. O presidente da mantenedora, o presidente da APESC, professor Ervino Hoelz, professor de Biologia, ele se reportava ao gabinete do prefeito. Todo mundo sabia disso. Isso antes ainda do prefeito Arno Frantz. Eu não vou lembrar quem era. Mas que foi sempre, tirando o Edmundo Hoppe, que era do MDB, todos os outros foram Arena/PDS, todos. Mas era isso, alguém ia lá com alguma demanda ou reivindicação e já sabia, o professor Ervino foi falar com o prefeito. E a gente ficava preocupado. Eu pego o finzinho

Barbarói, Santa Cruz do Sul, n.59 - número especial, p.<113-154>, Ago./Set. 2021 
disso, eu pego o último ano da gestão do professor Ervino. Então, o fato de a gente dizer "nós queremos liberdade em relação à prefeitura e, portanto, liberdade em relação às elites econômicas locais", fortalecia a nossa posição entre estudantes e professores. Agora, se tivéssemos perdido aquela eleição, com certeza a história toda seria outra. Aquela eleição de 1986 foi decisiva na continuidade de todo o processo, embora essa tensão continue até hoje, especialmente em relação à presidência da mantenedora. Mas ali, naquele momento, nós conseguimos consolidar o espírito democrático, depois de ganhar as eleições para direção geral. A partir daí todo o processo foi conduzido pelo professor Wilson como diretor geral, pelo professor Campis como vice-diretor geral, pela professora Maria Kipper como diretora da faculdade de Filosofia, pela professora Miriam Burgos na escola superior de Educação Física. Era basicamente isso. Do outro lado tinha a FACOSUL (Economia, Contábeis, Administração), cujo diretor era o professor Flávio Haas, liderança empresarial assumidamente de direita. E tinha a faculdade de Direito, cujo diretor não tinha um envolvimento maior com a política local, era mais uma referência moral, um típico liberal brasileiro, dizendo-se neutro, mas sempre pendendo para o lado do poder econômico. Mas, então, esse processo conduzido por quem estava disposto a fazer política e sabia fazer política, que eram a professora Maria na faculdade de Filosofia, professora Miriam, o Campis, o Wilson na direção geral, o professor Paulo Pinheiro Machado na coordenação dos cursos de férias. Com base na atuação dessas pessoas, ocupando esses cargos, a gente conduziu o processo de transformação em universidade e conseguimos aprovar, nos documentos legais, que o reitor eleito assumisse também a presidência da mantenedora. Então, elege-se o reitor e, automaticamente, o reitor assume a presidência da mantenedora. E isso é estatutário da APESC. E, desde muito tempo, a mudança desse artigo do Estatuto da APESC vem sendo tentada por iniciativa da ASSEMP, da ACI e outras entidades empresariais.

É importante isso. O reitor é automaticamente o presidente da mantenedora. As eleições na APESC são para o Conselho Superior, para escolher os membros do Conselho. E esta é uma eleição complicada, pesada, é uma eleição feita em assembleia. São 7 ou 8 membros, alguns membros são natos neste conselho, como é o caso de reitor, pró-reitor de administração, presidente da associação de docentes. Mas, além disso, tem 7 ou 8 membros que são votados. E nessa eleição é importante se construir maioria, porque ele define muitas das decisões. Mas, repito e repito, o presidente da APESC é sempre o reitor da universidade.

Isto foi tentado mudar pela ACI e ASSEMP. Várias vezes. E já houve, mais de uma vez, um grande estremecimento. Na reeleição da professora Carmem, o professor Flávio Haas avaliou que não valia a pena tentar de novo naquele momento. Então, o professor Flávio Haas, que foi diretor da FACOSUL por anos, foi professor da universidade por anos, que é diretor da ASSEMP atualmente, que foi diretor da ACI desde que eu estou em Santa Cruz do Sul, que já foi da direção da FIERGS em diversas gestões e sempre foi membro do conselho superior da APESC, desde que estou aqui, é o porta-voz dessa ideia de que a UNISC se afastou da cidade, e que se a UNISC estivesse sob o comando do empresariado local ela seria uma agência de desenvolvimento econômico para o município. $\mathrm{E}$, para isso, seria preciso dirigir a APESC, ter um representante do empresariado como presidente da APESC para, a partir da mantenedora, fazer mudanças na mantida. Porque, na prática, a UNISC sempre manteve a APESC. Economicamente, financeiramente, politicamente, a UNISC manteve a APESC. É Barbarói, Santa Cruz do Sul, n.59 - número especial, p.<113-154>, Ago./Set. 2021 
muito engraçado, mas se não fosse essa mantida, a mantenedora não existiria. Claro, depois se diversificou, com a APESC-Saúde, com a aquisição do Hospital Santa Cruz, mas continua sendo a UNISC que mantém a APESC e avaliza o hospital.

Tanto é que a direção geral do hospital presta contas para o conselho universitário. A prestação de contas do ano financeiro do Hospital Santa Cruz é para o conselho universitário e só depois para a assembleia comunitária da APESC. Mas, primeiro, aqui. A prestação de contas da reitoria da UNISC é para o conselho universitário, marcada para a mesma reunião em que o hospital presta contas. E nós, no conselho universitário, aprovamos ou não a prestação de contas do hospital. Então, a UNISC é uma mantida que, na verdade, não está em igualdade de condições com as outras.

\section{Entrevistadores:}

Mas isso decorre da condição do hospital, um hospital escola?

\section{Marcos Moura Baptista dos Santos:}

Não sei dizer. Não sei dizer exatamente. Porque a condição de ser hospital escola, no início não se conseguiu. E aí, sim, tem algumas necessidades que o hospital tem que cumprir para se manter como hospital de escola, não sei se tem.

Então, isso é interessante de pensar na política local. Mas resumindo, sim, há um grupo de dirigentes que apostou na democracia como condição para construir a universidade e isso começou lá por meados dos anos oitenta do século passado.

\section{Entrevistadores:}

E esse grupo? Ele sempre teve coesão política e ideológica? Pensando em termos da compreensão do que seria um projeto de universidade comunitária, com gestão democrática. Por que aqui também se coloca a própria necessidade de administrar a Instituição, de assumir questões burocráticas que podem provocar tensões quando se discute lógicas administrativas e lógicas comprometidas com a participação na gestão. Nesse sentido, pode-se falar também que o modelo democrático interno foi apropriado por uma determinada leitura?

\section{Marcos Moura Baptista dos Santos:}

Eu concordo com isso que vocês levantam. Eu lia na época muito sobre teoria das elites, o Robert Michels, o Pareto, e em muitos momentos me enxergava ali como sendo parte de uma elite que tinha viabilizado a democracia, mas que impedia o aprofundamento da democracia. A gente falava na época em "o grupo". “Ah, hoje tem reunião do grupo". Era o grupo de professores. E esse "grupo", em vários momentos os colegas diziam: "ah, vocês do grupo tinham que ampliar isso". Eu me lembro de colegas que, em momentos diferentes, ainda nos anos noventa, mais de uma vez chegaram para mim e disseram: "eu também penso, eu não estou sendo convidado a pensar, eu também sou um intelectual, eu também penso, vocês me chamam para aprovar, não me chamam para formular, não dá para apoiar vocês". E isso foi

Barbarói, Santa Cruz do Sul, n.59 - número especial, p.<113-154>, Ago./Set. 2021 
dito mais de uma vez. $\mathrm{O}$ apoio era no voto, depois, porque era a alternativa que tinha, mas, efetivamente, vários colegas passaram a ficar descontentes com o fato de que havia, de certa maneira, uma coisa assim: quem pensa, quem formula, quem planeja, quem propõe as decisões, são aqueles que, historicamente, naquele momento, estavam lá e tomaram a frente do processo. E quem chegou depois, porque chegou depois, não era ouvido e incorporado. Um colega da história, que já não está aqui, está na UFSM, o professor Remedi dizia isso: “eu só não estava naquela luta de vocês porque eu fui contratado aqui em 1994, 1995, senão eu estaria. Então, agora, por causa disso eu não posso fazer parte?" Então, teve vários momentos assim, "ah, esse grupo não foi capaz de criar novas lideranças", "ficou restrito", "não soube incorporar novas pessoas". E tem muita gente, penso eu, no nosso antigo departamento de Ciências Humanas, que, talvez pela afinidade do departamento, relevava um pouco isso, mas que também deveria estar se sentindo excluído dessas decisões. O professor Valter Freitas, mesmo, mais de uma vez ele discutia por que ele, sendo membro do grupo, era o único dos fundadores da democracia da UNISC que nunca tinha tido cargo na reitoria. Ele veio pedir para ser indicado para Pró-Reitor de Administração. E o que que ele dizia? "Eu sou o único que não foi, todos os outros tiveram aí, por que eu não?" Porém, mesmo crítico e insatisfeito, ele nunca rompeu com o grupo e nos apoiou enquanto esteve aqui, até ser demitido, já na gestão do professor Thomé.

E isso pesou, penso eu, na eleição de 2013, quando a candidatura do João Pedro perdeu para a Carmem Lúcia. Nós fizemos, eu estava na coordenação da campanha do João, nós fizemos uma tentativa de abrir, e essa tentativa de abrir era olhar para os lados e ver quem incorporar. E aí a gente se deu conta que não tinha nada orgânico, que a gente nunca foi um grupo organizado. E a gente acabou trazendo nomes que nunca tinham aparecido, como foi o caso da Ana Flávia, que era nova na instituição; o Luciano Duro, que também era novo. Mas que não eram orgânicos. Luciano, excelente professor, pessoa com todas as raízes democráticas e tal, mas ele foi chamado naquele momento e nunca mais. Ana Flávia foi chamada porque a gente precisava entrar na área do negócio, na área da Administração, da Economia, quem seria lá? Era um pouco isso, não era uma coisa que tivesse uma discussão mais sistemática, mais organizada.

\section{Entrevistadores:}

Em sua avaliação, então, faltou habilidade política na condução do processo? Num determinado momento, por exemplo, João Pedro chegou a falar em reunião do Departamento que estava se sentindo como se tivessem "puxado o tapete" dele. Ou seja, expressou que sentia ter perdido poder na discussão do processo decisório.

\section{Marcos Moura Baptista dos Santos:}

Faltou! O grupo tinha se fragmentado. A Carmem Lúcia, por exemplo, está nesse grupo desde o início. Ela participa do grupo desde o início, o departamento de Educação foi muito importante. Ieda, Helga, Carmem Lúcia são pessoas muito importantes na fundação desse grupo. Aí, então, acho que nesse momento aí o grupo já está fragmentado mesmo. E está fragmentado justamente porque ele foi ficando em torno de alguns nomes, circulava em torno

Barbarói, Santa Cruz do Sul, n.59 - número especial, p.<113-154>, Ago./Set. 2021 
de alguns nomes, já não fazia mais. Eu penso que a própria construção da candidatura do João Pedro, olhando a posteriori, demonstra essa fragilidade política. O que aconteceu? Aconteceu que ele acreditou numa fala que na política não se pode acreditar. Na reunião da reitoria, eu não estava mais na reitoria, mas eu tenho relato de ambos os lados. O professor Tomé, que era o Reitor, disse: "a gente não vai, como vários nomes da reitoria têm interesse, discutir isso até agosto". Mas em agosto as coisas já estavam decididas, porque independente de uma decisão, a Carmem já tinha saído (e eu faria a mesma coisa) a conversar com cursos e departamentos: "eu pretendo ser candidata, se eu for candidata eu gostaria muito do apoio de vocês". Ela não disse que era, ela disse que queria. O João Pedro esperou até agosto, e aí ele saiu para fazer campanha, e aonde ele chegou as pessoas disseram: "ah, eu já me comprometi com a Carmem". Então, a Carmem fez política, e nós ficamos acreditando que o adiamento da discussão era importante para não rachar a Reitoria. Mas esse era o discurso do Reitor, que insistia que a discussão poderia rachar a Reitoria e que ele não queria que isso ocorresse muito antes do término de seu mandato.

\section{Entrevistadores:}

Em algum momento vocês chegaram a discutir a possibilidade de João Pedro continuar numa Pró-Reitoria, ou então ser colocado como Vice-Reitor, com a Carmem na Reitoria?

\section{Marcos Moura Baptista dos Santos:}

Sim. E desde o início, quer dizer, teve muito aí o Thomé, que está nesse grupo desde o início, mas que desde o início é visto com desconfiança por este grupo. E o Thomé está nesse grupo porque foi chamado, puxado pelo Wilson, e é mantido sob a sombra do Wilson o tempo inteiro, até que começa a ter um caminho próprio. Eu lembro que a definição da candidatura do Thomé foi tensíssima na reitoria, que fomos eu e a Maria Kipper que propusemos o nome do Thomé. A gente que propôs, achava que era a hora dele ser. E foi muito tenso, porque a Carmem já queria. João Pedro não estava ainda ali, mas a Carmem queria.

Carmem já queria. E aí, sim, agora falta uma coisa que eu não sei, que eu não vi, que não me contaram, mas que eu tenho certeza que aconteceu. Nesse momento, o Thomé prometeu o rodízio para a Carmem. Então, eu quero crer que lá atrás já estava definido que primeiro seria Thomé e depois a Carmem. E é isso, porque de alguma maneira era essa a ordem.

No segundo mandato do Campis, o João Pedro já entra, mas naquele momento já estava certo que seria o Thomé, embora o Luiz Augusto se afaste fortemente do Thomé. Fica claro a cisão entre eles. Luiz Augusto não faz questão de esconder isso e mantém uma relação apenas institucional. E isso ficou ainda mais claro quando Luiz Augusto assumiu como Vice-Prefeito, nas relações em função do hospital, tem enfrentamentos grandes entre a UNISC e a prefeitura, por conta do plantão, do PA, de repasse de verbas; então, tinham discordâncias muito grandes.

\section{Entrevistadores:}

Barbarói, Santa Cruz do Sul, n.59 - número especial, p.<113-154>, Ago./Set. 2021 
Mas chegava a ter conflitos institucionais? Ou seja, o que você está dizendo é que, durante o periodo em que Campis esteve na Prefeitura, essa nem sempre foi uma aliada da Universidade no processo de gestão do Hospital?

\section{Marcos Moura Baptista dos Santos:}

Sim. Isso. Na verdade, a leitura que o Campis faz disso é de que a UNISC se aproveitou da prefeitura. A prefeitura botou muito dinheiro, e a UNISC nunca reconheceu isso.

Mas, voltando para a candidatura do João Pedro, o que aconteceu? A gente tinha claro, nas reuniões que a gente fez, para ver se isso alcançava ou não. A gente já tinha claro que não teria o apoio do Thomé, por razões óbvias. E que o Thomé lançaria um candidato. E a gente começava a achar que seria a Carmem, que a Carmem teria o apoio dele, embora isso não ficasse muito claro. E aí nós pensamos, e eu acho que esse movimento é do coletivo, aquele que teria mais chance. Foi o grupo que fez esse movimento. Os remanescentes do grupo. Que foi o seguinte: "temos que fazer um acordo. Carmem como vice não vai rolar, ela não vai topar. Então, a gente pode fazer um acordo com o João Pedro como vice, porque vice eleito fica o mandato inteiro, se pode até esvaziar a função, mas se não pode mandar embora". E eu acho que foi aí que inviabilizou o acordo com a Carmem.

O João Pedro falou isso com o Thomé e com a Carmem, dizendo que queríamos a PROGRAD e a PROAD. Então, hoje o Rogerinho ainda diz isso com todas as letras: "a gente tinha que ter bancado o João Pedro para vice da Carmem e só isso".

\section{Entrevistadores:}

Tem uma questão que pode ser melhor esclarecida, relacionada à escolha de quem seria o candidato da Reitoria ao final do segundo mandato do professor Luiz Augusto. Como ocorreu aquele processo e em que condições o professor Thomé foi escolhido?

\section{Marcos Moura Baptista dos Santos:}

Certamente nós pensávamos com mais nomes. Mas, veja, o professor Rogério, por exemplo. Ele não quis. O Rogério disse com todas as letras, "não é meu perfil, eu não quero, eu prefiro outra coisa, eu até assumo uma Pró-Reitoria novamente". E, é claro, o Rogério tinha grandes possibilidades de ser um nome de consenso na Universidade, sempre reconhecido como uma pessoa ponderada. Mas ele não quis. Eu lembro que insisti com ele, internamente, mas foi uma decisão pessoal, que a gente aceitou. O meu nome. Bem, eu tinha questões, inclusive políticas, que indicavam fragilidade na candidatura, abriria flancos que, avaliamos, nos colocariam em riscos desnecessários. E eu não estava muito interessado em fazer os enfrentamentos necessários. E tinha uma avaliação, da qual eu compartilhava, que eu, pela própria condição de Pró-Reitor de Planejamento, assumi determinadas frentes com o objetivo de evitar colocar divergências de frente com o Reitor. Então, de alguma forma eu era "o cão de guarda", quem sai para brigar em alguns momentos. Aliás, em inúmeras vezes eu fui para reuniões para fazer o papel do brigador, com a clareza de que as pessoas iriam reclamar com o Reitor e que o Reitor iria me desautorizar. E isso era uma estratégia clara, era combinado, como ações que, em determinados momentos, são importantes inclusive para que a discussão

Barbarói, Santa Cruz do Sul, n.59 - número especial, p.<113-154>, Ago./Set. 2021 
possa avançar. Mesmo esse meu comportamento criava dúvidas, pois quem assume a Reitoria precisa ter uma capacidade de negociação que, em muitos momentos, eu dava demonstração de não ter.

\section{Entrevistadores:}

Também nessa discussão está em questão um desejo de ver um momento de guinada. Um momento em que se pudesse identificar mudanças importantes na condução da Universidade, abrindo-se espaços para a relativização de determinadas concepções que até então estavam mais presentes. Mas, nessas horas, é preciso cuidado, inclusive para não identificar essas mudanças com uma única pessoa. Pois, naqueles anos 1990, havia um processo de mudanças no ensino superior brasileiro, com o crescimento das privadas, com a maior competição que a UNISC passou a ter mesmo em Santa Cruz do Sul. Ou seja, havia um contexto que colocava desafios grandes para a gestão de uma Universidade comunitária.

\section{Marcos Moura Baptista dos Santos:}

Eu penso que as mudanças maiores ocorreram já na gestão do professor Thomé. E foram mudanças pelas decisões do Reitor. Por suas visões acerca da Universidade naquele momento, de qual gestão era necessária, de qual modelo de Universidade. Agora, a própria eleição do Thomé [...] poderia ter sido outro candidato. E, talvez, se fosse outro teríamos naquele momento um racha, que seria muito mais fácil para quem estava mais próximo do Luiz Augusto superar e, inclusive, neutralizar. Eu penso que depois que o Thomé assumiu a Reitoria, bem, ele assumiu voos próprios, brilho próprio, ele ganhou força política, fez nascer articulações dentro e fora da Universidade, e a partir de então ele criou condições também para se distanciar de quem poderia avaliar como sendo "um grupo de esquerda". E Thomé nunca foi de esquerda. Ele é um liberal, eu trabalhei com ele, ele sempre teve muito respeito pela democracia, mas nunca foi entusiasta de uma democracia mais profunda, uma democracia com maior participação direta.

\section{Entrevistadores:}

No período que antecedeu à eleição do professor Thomé para Reitor, você assumiu um cargo importante na Reitoria: Pró-Reitor de Planejamento. Gostaríamos de ouvir uma avaliação sua sobre essa participação na Reitoria, na condição de Pró-Reitor de Planejamento.

\section{Marcos Moura Baptista dos Santos:}

Eu entrei em 1998, quando foi criada a PROPLAN. Na verdade, foi criada a PROPLAN e eu fui assumir a PROPLAN. Era um espaço que, desde 1994, eu vinha insistindo para que fosse criado. Talvez antes. O próprio texto que escrevi naquela época para a Barbarói já falava de algo parecido, o nome era diferente, eu chamava de "Escritório de Planejamento". Mas já estava lá. Quase tudo aquilo que escrevi, naquele artigo, foi criado dentro da PROPLAN. E era a ideia de que o planejamento era importante. Mas não qualquer planejamento, pois sempre defendi a ideia de um planejamento estratégico. Eu tinha meus resquícios de

Barbarói, Santa Cruz do Sul, n.59 - número especial, p.<113-154>, Ago./Set. 2021 
sociólogo e eu dizia: "olha, o estratégico não tem nada que ver com o que o pessoal da administração chama de estratégico. Não é isso. Estratégico é uma coisa que eu faço hoje pensando em estar em algum lugar lá na frente; não é um planejamento para daqui 50 anos. É um planejamento para hoje, que permitirá que, se o mesmo for executado, daqui 50 anos eu esteja onde quero estar". Então, não é fazer plano "concretíssimo". Tanto que a primeira coisa que eu fiz foi criar o plano geral de ação, que é o plano anual, depois a gente modificou o caráter dos PDIs e eles passaram a ser documentos vinculativos. Tudo tem que estar vinculado ao PDI para poder acontecer.

Até então, o PDI era mais para atender exigências do MEC: "tem que fazer, então a gente faz”. E ele passou a ter cada vez menos discurso e menos coisas bonitinhas ali, passou a ser uma atividade, uma ação com cronograma, com previsão orçamentária. Porque, com isso, a gente conseguiu discutir melhor nossas ações: "olha, se fizermos isso vamos alcançar tal coisa, que nos permitirá alcançar outra e tal". Então, foi muito assim o foco todo da PROPLAN. Vejam: isso é planejamento e desenvolvimento institucional. E aí eu tive, tentei centralizar uma série de coisas, trazer para a PROPLAN coisas que eram, até então, da PROAD, da Administração. Informática eu trouxe pra PROPLAN, criamos um comitê, depois nós criamos os fóruns de gestão, em que as duas pró-reitorias trabalhavam juntas. Eu trabalhei muito com o Thomé. E a única coisa que eu não consegui, do que eu queria, que eu não consegui fazer, foi trazer o orçamento para a PROPLAN. O orçamento sempre foi feito pela PROAD, e eu sempre disse: "orçamento feito pela Pró-Reitoria de Administração é um orçamento para tocar o dia a dia; um orçamento feito Pró-Reitoria de Planejamento é o orçamento que a universidade precisa ter, não é um orçamento só para fechar conta”. E, bom, aí vinha o discurso: "quem tem que fazer planejamento é quem entende de gestão, de administração, de finanças, e é na PROAD onde tem isso tudo". Nós conseguimos transformar o planejamento numa coisa conjunta das duas Pró-Reitorias, mas isso só valeu enquanto havia maior afinidade entre as duas Pró-Reitorias. Quando eu saí da PROPLAN, penso eu, a PROAD pegou o orçamento só para eles novamente, inclusive porque o que foi feito, de aproximação do trabalho das duas Pró-Reitorias, não estava escrito em lugar nenhum. Então, era uma questão também de relação entre os dois Pró-Reitores. Quando a relação terminou, pois eu saí da Pró-Reitoria, as próprias ideias perderam força.

Mas, sem dúvidas, no período em que estive na PROPLAN, entre março de 1999 e dezembro de 2001, pessoalmente foi um período muito rico. Ainda que eu tenha me afastado da Sociologia, aprendi muitas coisas. E consegui fazer o principal que eu queria fazer. Eu não consegui o que considerava muito importante, que era ter recursos para liberar dois ou três professores, com todas as suas horas-atividades, para simplesmente pensar o futuro da Universidade. Algo assim. Chamar esses professores e dizer: "vocês estão liberados para pensar a Universidade, vão fazer somente isso e nada mais do que isso, vão levantar ideias, mesmo que essas ideias inicialmente pareçam malucas, e depois vamos discutir elas. Vocês não terão que prestar conta de nada, a não ser dessa tarefa”. E, inclusive pelas dificuldades financeiras, isso não foi possível. E eu não consegui convencer o Reitor da importância de um projeto como esse.

Barbarói, Santa Cruz do Sul, n.59 - número especial, p.<113-154>, Ago./Set. 2021 
Os conflitos com a PROAD, que fiz referência, nunca foram conflitos importantes. Foram questões da gestão. Na verdade, eram conflitos que apareciam muito no comitê gestor da Internet. Ali, a gente brigava muito, porque implicava definir quem iria administrar o setor de informática, que era o setor de mais recursos da casa. E aí, sim, a gente teve sempre brigas. A gente criou o comitê gestor, eu e o Jaime coordenamos, e veio muito discurso técnico que me calava. O Jaime trazia o Hilton, coordenador do setor de informática, que dizia: "não dá para fazer". E eu dizia: “ah, mas eu li que dá". E ele dizia: “ah, mas ler é uma coisa, outra coisa é fazer, eu estou lá todo dia, não dá". E nisso muitas coisas que eu gostaria de fazer deixaram de ser feitas. Acho que metade delas não dava mesmo, mas a outra metade daria. E, embora formalmente tivesse um comitê gestor, era a PROAD que dava as cartas. E, bom, depois que eu saí disso, eu continuei alguns anos falando na reunião geral da importância de atualização do parque de informática, que nunca foi atualizado, porque nunca tinha dinheiro. Eu sempre achei que tinha que botar muito mais dinheiro na informática, que tinha que ter muito mais rede, muito mais coisa aí. E sempre foi uma visão mais de hardware: "não, tem que atualizar computador, a gente tem que ter um computador rápido". E eu dizia: "não, a gente tem que ter uma rede bem estruturada”. Então, ali tinha uma divisão de ideias, e que eu sempre perdi. Mas continuo com essa opinião, que o problema maior é a rede, mas a gente sempre pensou em máquinas. Então, era mais uma ideia lógica que eu tinha. Mas foi isso, sempre foi muito tranquilo trabalhar com a PROAD.

As divergências eram em função do orçamento, sempre brigamos por orçamento, o professor Thomé mais pragmático, eu pensando em outras coisas. E aí, uma lógica que tem a ver com visão de macroeconomia, que eu achava que o endividamento não era um problema para crescer, só crescia com endividamento. E ele queria fechar as contas todo ano, do zero a zero, nada de vermelho. Era uma questão de honra para um administrador.

Não faz mal nenhum que o nosso déficit seja de 20 milhões, se esse déficit for financeiro. Porque daí significa que a gente um dia vai pagar, e aí é só a gente mudar o perfil para dívida de longo prazo. Foi assim que a gente construiu, tudo que construímos de prédio. Com uma linha do BNDES, que foi aberta e que a gente conseguiu entrar. Tudo foi construído com endividamento de longo prazo, endividamento financeiro. Porque não pode é ter déficit econômico, não pode é faltar dinheiro de verdade. Se estou pendurado em papagaio não é problema, a gente empurra. Não vão quebrar a Universidade. É grande demais para quebrar, não vão... o governo não vai. O que o governo pode fazer? É nos federalizar, não seria uma derrota, em função da dívida virar federal. Fora isso, eles não podem. E aí foi uma divergência grande. Então, aquele período foi um período que aprendi muita coisa, aprendi coisas que não tinha a menor ideia de que existiam na Universidade, como funcionavam, como se relacionar com as pessoas. Outra coisa que eu penso que foi, que eu tenho muito orgulho, é a ouvidoria. A ouvidoria, conforme nós pensamos e criamos, ela estava na PROPLAN, a ouvidoria era ligada ao gabinete do Pró-Reitor de Planejamento, porque eu pensava a ouvidoria especialmente como um local para ter informação para planejamento. As pessoas vão reclamar, e eu vou saber que isso é problema. As pessoas vão elogiar, e eu vou saber que isto é bom, que funciona. Em função disso, a gente toma decisões, era muito para isso a ouvidoria. Mas essa minha posição começou a deteriorar a minha relação com todo o departamento de educação, porque o departamento de educação entendeu que a ouvidoria era

Barbarói, Santa Cruz do Sul, n.59 - número especial, p.<113-154>, Ago./Set. 2021 
um AI-5, que era um instrumento para dedurar, para o Pró-Reitor saber de coisas. E tomou outra direção.

\title{
Entrevistadores:
}

Professor Marcos, muito obrigado. Não precisamos dizer que sua participação nesse projeto é de grande importância. Não somente pela sua reflexão acerca das ciências humanas na formação universitária, sua participação na gestão do Departamento de Ciências Humanas, mas, também, pela sua importante participação na gestão da UNISC.

\section{HUMAN SCIENCES AND UNIVERSITY TRAINING: AN ANALYSIS FROM THE UNISC EXPERIENCE.}

\begin{abstract}
:
In the interview, Professor Marcos Moura Baptista dos Santos considers his experience in the management of UNISC, both as Pro-Rector of Planning and as Head of the Department of Human Sciences, to analyze the changes that have occurred, throughout history, in the experiences of Community Universities. Contextualizes the political process that resulted in the creation of UNISC in the early 1990s, evaluates the changes that have occurred in the different UNISC administrations and discusses the recent changes that occurred in a context of economic and political crisis that has repercussions on the University's own historical experience in Brazil. At the same time, Professor Marcos considers the changes that occur in the university formation process, especially in Community Universities, considering these changes since the commitments assumed by Community Universities in their stories.
\end{abstract}

\section{Keywords:}

Community Universities; University Management; University education; Humanities and University Formation.

\section{Sobre os autores:}

Marcos Moura Baptista dos Santos é mestre em Ciências Sociais pela Pontifícia Universidade Católica do Rio Grande do Sul (PUC-RS). Tem graduação em Ciências Sociais pela Universidade Federal do Rio Grande do Sul (UFRGS) e especialização em Antropologia Social pela UFRGS e em Administração Universitária pela Organização Universitária Internacional (OUI). Foi Pró-Reitor de Planejamento e Desenvolvimento Institucional da Universidade de Santa Cruz do Sul (UNISC) no período entre 1998 e 2001. Foi também chefe do Departamento de Ciências Humanas da UNISC no período entre 2016 e 2017. É professor

Barbarói, Santa Cruz do Sul, n.59 - número especial, p.<113-154>, Ago./Set. 2021 
adjunto da UNISC. Tem experiência docente na área de Sociologia e Antropologia, com ênfase em Sociologia da Comunicação, Sociologia do Direito, Sociologia Aplicada à Saúde e Políticas Públicas de Saúde, além de atuar como tutor no curso de Medicina. Tem experiência em pesquisa na área de abuso de drogas e redução de danos e em extensão na área de formação de professores. Após uma década pesquisando o sistema da educação superior, em temas como avaliação institucional, universidades comunitárias e gestão universitária, desde 2008 tem direcionado seus estudos para o sistema de saúde, com ênfase para políticas públicas de formação de profissionais de saúde e estudos de bioética. Coordenou na UNISC o PET-Saúde/Vigilância em Saúde 2013-2015 e o PET-Saúde/Vigilância em Saúde 2010-2012; e foi coordenador adjunto do PROPET UNISC (Pró-Saúde III e PET-Saúde/Redes de Atenção). Atualmente é membro da CGAL (Comissão Gestora Local) do Pró-Saúde na UNISC. A partir de junho de 2016 faz parte do NDE (Núcleo Docente Estruturante) do curso de Odontologia da UNISC. É membro da CEUA (Comissão de Ética na Utilização de Animais), desde 2012, e, em 2014, participou do CEP (Comitê de Ética em Pesquisa), ambos na UNISC. Mantém o blogue Professor Caco (https://cacobaptista.wordpress.com/), com artigos, palestras e aulas.

César Hamilton Brito de Goes é graduado em Ciências Sociais, Mestre e Doutor em Sociologia pela Universidade Federal do Rio Grande do Sul (UFRGS). É professor e pesquisador na UNISC (Universidade de Santa Cruz do Sul), onde atua no Departamento de Humanidades, Ciências e Educação.

Marco André Cadoná é graduado em Filosofia, Mestre em Sociologia (Universidade Federal do Rio Grande do Sul) e Doutor em Sociologia Política (Universidade Federal de Santa Catarina). Professor e pesquisador na UNISC (Universidade de Santa Cruz do Sul), onde atua no Departamento de Humanidades, Ciências e Educação e no Programa de Pós-Graduação em Desenvolvimento Regional.

Barbarói, Santa Cruz do Sul, n.59 - número especial, p.<113-154>, Ago./Set. 2021 